\title{
Comprehensive evaluation of the palatability and chemical defenses of subtidal macroalgae from the Antarctic Peninsula
}

\author{
Charles D. Amsler ${ }^{1, *}$, Katrin Iken ${ }^{1,5}$, James B. McClintock ${ }^{1}$, Margaret O. Amsler ${ }^{1}$, \\ Kevin J. Peters ${ }^{1}$, Joanna M. Hubbard ${ }^{2}$, F. Bruce Furrow ${ }^{3}$, Bill J. Baker ${ }^{4}$ \\ ${ }^{1}$ Department of Biology, University of Alabama at Birmingham, Birmingham, Alabama 35294-1170, USA \\ ${ }^{2}$ Anchorage School District, Anchorage, Alaska 99516, USA \\ ${ }^{3}$ Department of Chemistry, Florida Institute of Technology, Melbourne, Florida 32901, USA \\ ${ }^{4}$ Department of Chemistry, University of South Florida, Tampa, Florida 33620, USA
}

${ }^{5}$ Present address: Institute of Marine Science, School of Fisheries and Ocean Sciences, University of Alaska Fairbanks, Fairbanks, Alaska 99775-7220, USA

\begin{abstract}
The palatability of 35 non-encrusting, subtidal macroalgal species collected from the vicinity of Palmer Station, Antarctica $\left(64^{\circ} 46^{\prime} \mathrm{S}, 64^{\circ} 03^{\prime} \mathrm{W}\right)$, was determined in laboratory bioassays utilizing sympatric sea stars and fish known to consume macroalgae in nature. Overall, $63 \%$ of the macroalgal species offered to sea stars and $83 \%$ of the macroalgal species offered to fish in thallus bioassays were significantly unpalatable. This included all of the ecologically dominant, overstory brown macroalgae in the region. When organic extracts of unpalatable macroalgal species were incorporated into artificial foods, $76 \%$ of the species unpalatable as thallus to sea stars were also unpalatable to them as extract, and $53 \%$ of the species unpalatable as thallus to fish were also unpalatable to them as extract. If either sea stars or fish rejected thallus of a macroalgal species, palatability of organic extracts of that species to herbivorous amphipods was determined: $63 \%$ of such algal species were unpalatable as extract to the amphipods. It was concluded that antarctic macroalgae are commonly unpalatable to sympatric consumers and that much of this unpalatability is the result of chemical defenses. As a whole, neither thallus toughness nor a variety of nutritional quality parameters appeared to be related to macroalgal palatability. We also tested the hypothesis that nitrogen-containing metabolites should be common in macroalgae from nitrogen-replete, carbon-limited environments such as the coastal waters of Antarctica. Macroalgal acid extracts targeting nitrogenous secondary metabolites were subjected to thin-layer chromatography analysis; no such compounds were detected.
\end{abstract}

KEY WORDS: Chemical defenses · Antarctica $\cdot$ Herbivory $\cdot$ Macroalgae $\cdot$ Resource allocation model · Carbon-nutrient balance hypothesis

Resale or republication not permitted without written consent of the publisher

\section{INTRODUCTION}

Macroalgae dominate shallow benthic communities on hard substrates along the western Antarctic Peninsula, often covering $>80 \%$ of the bottom, with standing biomass levels comparable to temperate kelp forests (Amsler et al. 1995, Brouwer et al. 1995, Quartino et al. 2001). Several species of large, perennial brown algae are particularly abundant. Desmarestia menziesii and/ or $D$. anceps typically dominate in shallow waters down to approximately 10 to $20 \mathrm{~m}$, with Himantothallus grandifolius dominating from 10 to $20 \mathrm{~m}$ down to 40 m or deeper (DeLaca \& Lipps 1976, Zieliński 1990, Amsler et al. 1995, Brouwer et al. 1995, Quartino et al. 2001). Cystosphaera jacquinotii and D. antarctica, an annual to biennial species, can be co-dominant in some locations (Zieliński 1990, Chung et al. 1994, Amsler et al. 1995). Although standing biomass is high, 
overall macroalgal species diversity is low. Wiencke \& Clayton (2002) estimate that there are only 120 to 130 species of macroalgae known for the continent of Antarctica as a whole, and we are aware of only 1 report (Moe \& DeLaca 1976) documenting more than approximately 30 species of subtidal macroalgae at any single study area in Antarctica.

It has been suggested for a number of years that macroalgae probably play important roles in benthic food webs in both shallow and deeper waters along the Antarctic Peninsula (e.g. Neushul 1965). Macroalgae have been recognized as a major source of dissolved and particulate detritus along the Antarctic Peninsula (Dawson et al. 1985, Fischer \& Wiencke 1992 and references therein). Numerous animals are known to consume macroalgae (e.g. Brand 1974, Richardson 1977, McClintock 1994, Iken et al. 1997, 1998, Graeve et al. 2001, and references therein), with macroalgae constituting most or all of the gut contents in some species (e.g. Brand 1974, Iken et al. 1997, Graeve et al. 2001). Dunton (2001) traced carbon from the large, ecologically dominant brown macroalgae, using stable isotope methods, and reported that these algae are particularly important primary producers in shallow-water communities. Brown-macroalgae-derived carbon was a major component in epibenthic fish and in numerous invertebrate groups. Some was probably consumed directly by herbivores and some almost certainly entered the community via detrital food webs (Dunton 2001). There is only limited information, however, on the proportion of Antarctic macroalgal species palatable to sympatric consumers (Iken et al. 1998) and virtually no data on the relative importance of herbivory in structuring these algal communities.

Marine macroalgae are commonly unpalatable to potential consumers. Various factors that may decrease algal palatability have been discussed, for example, the structure, growth form, and thallus toughness (Littler \& Littler 1980, Steneck \& Watling 1982) and the low nutritional quality of algae (Duffy \& Paul 1992, Hay et al. 1994). Macroalgae can also contain chemical defenses to deter herbivores (McClintock \& Baker 2001). Tropical macroalgae have been considered to have more abundant and diverse chemical defenses than temperate species because of a higher level of selective pressure through grazing in tropical ecosystems (Gaines \& Lubchenco 1982, Hay \& Fenical 1988, Hay \& Steinberg 1992, Targett \& Arnold 1998). While some temperatetropical comparisons of macroalgal chemical defenses have been made (e.g. Steinberg \& Paul 1990, Van Alstyne \& Paul 1990, Bolser \& Hay 1996, Cetrulo \& Hay 2000 ), other than a report on the only 2 fleshy macroalgal species in McMurdo Sound, Antarctica (Ross Sea; Amsler et al. 1998), and a few species in King George Island (Antarctic Peninsula; Iken et al. 1998), there are no published reports on the presence of chemical defenses in polar macroalgae to compare with data from lower latitudes. If indeed macroalgal chemical defenses are more common in the tropics than in temperate zones, would one predict that they will be less important still in polar regions? An analogous situation occurred with respect to marine macroinvertebrate chemical defenses, which are also thought to be somewhat more common and important in tropical regions than at more temperate latitudes (Bakus \& Green 1974). This latitudinal hypothesis has recently been challenged in comparative studies (Becerro et al. 2003), and studies of the chemical ecology of Antarctic marine invertebrates have demonstrated that chemical, anti-predator defenses are indeed common in these animals (reviewed by Amsler et al. 2000, 2001a,b).

The resource allocation model (Coley et al. 1985) and the carbon-nutrient balance hypothesis (Bryant et al. 1983) predict, on evolutionary and ecological time scales respectively, that nitrogen-limited plants and macroalgae will have a relative excess of carbon and will produce non-nitrogenous secondary metabolites such as phlorotannins and terpenes as chemical defenses. Light-limited (i.e. carbon-limited) plants and algae, on the other hand, are predicted to utilize nitrogen-containing defenses such as alkaloids, which are often effective at much lower concentrations. Some studies with macroalgae support the hypothesis that nutrient-limited brown algae can have increased levels of phlorotannins (reviewed by Cronin 2001) although this is not always true (Peckol \& Yates 1997, Pavia \& Toth 2000), and the same pattern does not hold for macroalgal terpenes (reviewed by Cronin 2001). However, we are aware of no published research testing the hypothesis that carbon-limited macroalgae invest in nitrogen-containing defenses. The temperate and tropical macroalgae studied to date do produce nitrogen-containing secondary metabolites including alkaloids, but they are relatively rare even though such secondary metabolites are abundant in nitrogenfixing marine cyanobacteria and in many groups of marine invertebrates (Baker 1996, Harper et al. 2001, Paul et al. 2001, Blunt \& Munro 2004). Several authors (Hay \& Fenical 1988, Hay \& Steinberg 1992, Cronin 2001) have speculated that nitrogenous secondary metabolites are so rare in macroalgae because it is very common for algae from temperate and tropical regions to be nitrogen-limited. However, that is not true in the coastal waters of Antarctica, where ambient nitrogen levels are high year round (Gordon \& Molinelli 1982, Harrison \& Cota 1991, Drew \& Hastings 1992) and where light is most often considered the limiting resource for algal productivity throughout the year (Holm-Hansen et al. 1977, Heywood \& Whitaker 1984, Weykam et al. 1996). Paleoceanographic obser- 
vations of Southern Ocean productivity and circulation patterns (Kennett 1977, Kennett \& Barker 1990) are consistent with these conditions having been present in Antarctic coastal waters for at least the past 15 million yr (J. Kennett pers. comm.). C:N ratios of Antarctic macroalgae are very low and tissue nitrogen contents are well above critical levels, indicating that nitrogen in fact does not limit growth (Weykam et al. 1996, Dunton 2001, Peters 2004, Peters et al. 2005). Consequently, Antarctica is an excellent place to test the hypothesis that carbon-limited, nitrogen-replete macroalgae should commonly produce nitrogencontaining secondary metabolites. This is not to imply that carbon limitation does not occur in macroalgae from other regions. The important distinction is that Antarctic macroalgae have had ample time to adapt to an environment where nutrient limitation is not a primary factor influencing growth over a wide geographic scale, and so this should not have constrained the evolution of nitrogen-containing defenses.

The objectives of the present study were as follows: (1) to examine the palatability of individual species of subtidal, non-encrusting Antarctic macroalgae to common, sympatric consumers known to consume macroalgae; (2) to determine whether unpalatable macroalgal species are rejected because of chemical defenses, physical defenses, or nutritional reasons; and (3) to take advantage of the unique nutrient environment of coastal Antarctica to test the prediction that nitrogen-containing secondary metabolites should be common in carbon-limited, nitrogen-replete macroalgae. Although macroalgae are overwhelmingly dominant in the structure of the communities we studied, the relatively low species diversity made it possible to take an exhaustive approach to some of these questions by looking at palatability and chemical defenses in all those species that are practical to collect in sufficient quantities.

\section{MATERIALS AND METHODS}

Collection sites and organisms. All subtidal macroalgae were collected by hand during SCUBA dives within $3.5 \mathrm{~km}$ of Palmer Station on Anvers Island off the western Antarctic Peninsula (64 $46.5^{\prime} \mathrm{S}, 64^{\circ} 03.3^{\prime} \mathrm{W}$; see Amsler et al. 1995 for map). Collections were made during 3 periods: early March to late April 2000, early November to late December 2001, and mid-February to late April 2003. Collection depths ranged from 2 to $39 \mathrm{~m}$.

Macroalgal taxonomy follows Wiencke \& Clayton (2002) with the exception of Trematocarpus antarcticus. This species is described as Kallymenia antarctica in Wiencke \& Clayton (2002) as well as in earlier pub- lications but is currently being transferred to the genus Trematocarpus (S. Fredericq \& R. Moe pers. comm.). The red macroalga designated herein as 'undescribed species $1^{\prime}$ is previously known from the western Antarctic Peninsula (R. Moe, C. Wiencke \& M. Clayton pers. comm.), but is so far not assigned to a specific species. It is a member of the family Kallymeniaceae and probably in the genus Pugetia (R. Moe, pers. comm.). Desmarestia antarctica, an annual/ biennial species (Wiencke et al. 1991), was primarily represented by relatively thin first-year thalli during our February-April collections $(2000,2003)$ and by thicker second-year thalli during our NovemberDecember 2001 collections. Because of these marked morphological differences between the seasons and the fact that $D$. antarctica can be locally dominant at some depth ranges in the Palmer Station area (Amsler et al. 1995), we separated first- and second-year thalli for all analyses. Acanthococcus antarcticus and an additional 4 or 5 non-encrusting red macroalgal species not identifiable to species level (and/or perhaps of undescribed species; R. Moe, pers. comm.) were collected, but only rarely and with insufficient numbers of individuals to include in bioassays. The filamentous brown alga Elachista antarctica was present, but individuals were too small to be used in any of the bioassays. In addition to the non-encrusting, subtidal macroalgal species examined in this study, at least 2 non-calcified, encrusting red macroalgal species (Gainia mollis and 1 or more Hildenbrandia sp.) and several species of calcified, encrusting red macroalgae (Corallinales) were also present subtidally in the study area, as were at least 6 species of non-encrusting, intertidal macroalgae.

The sea star Odontaster validus, the demersal fish Notothenia coriiceps, and the amphipod Gondogeneia antarctica were used as test organisms in feeding bioassays. O. validus ( 3 to $6 \mathrm{~cm}$ radius) was collected from the same general locations and over the same intervals as the subtidal macroalgae, with a small number of collections also being made in January 2002 and May 2003. N. coriiceps (length approximately 20 to $30 \mathrm{~cm}$ ) was primarily collected by hook and line along the shore and occasionally by hand during SCUBA dives in March through April 2000 and in November 2001 through January 2002. G. antarctica (3 to $6 \mathrm{~mm}$ total length) was collected along tide pools during the periods noted for subtidal macroalgal collections and supplemented during April and May 2003 by undamaged animals trapped by the station's seawater filters.

The intertidal macroalga Cladophora repens, used as a feeding stimulant in bioassays, was collected in early March 2000 and early March 2003. Because $C$. repens was not present in November or early December 2001 (very early in the growing season), it was 
supplemented by $C$. vagabunda collected in late July 2001 at Childs River, MA (USA), which is similar to Antarctic coastal waters in that it is nitrogen rich (Valiela et al. 2000). Both Cladophora spp. were freeze dried and ground to a fine powder using a pestle and mortar prior to use in artificial foods. The subtidal macroalga Palmaria decipiens used as a feeding stimulant in bioassays was collected in late November 2001. Freeze-dried $P$. decipiens was ground into small flakes using a pestle and mortar, and then the flakes were ground to a fine powder using a commercial coffee grinder. Freeze-dried Antarctic krill (Euphausia superba), used as a feeding stimulant in control pellets for sea star bioassays (see below), were obtained commercially (Argent Chemical Laboratories) and ground into a fine powder using a pestle and mortar.

Macroalgal processing and extract preparation. Freshly collected macroalgae were blotted and/or centrifugally spun to remove external water and then weighed wet. The thalli were then frozen at $-20^{\circ} \mathrm{C}$ and/or $-80^{\circ} \mathrm{C}$ until use in chemical extractions. Wetweight:volume ratios were determined by measuring the volume of seawater displaced by unfrozen subsamples of the macroalgal thalli in graduated cylinders. Wet:dry weight ratios were determined by weighing unfrozen thallus sub-samples before and after oven drying at $60^{\circ} \mathrm{C}$.

Previously frozen thalli were extracted in 3 changes (24 $\mathrm{h}$ each) of 1:1 $\mathrm{CH}_{2} \mathrm{Cl}_{2}$ : methanol, resulting in lipophilic extracts. This was followed by 3 changes (24 $\mathrm{h}$ each) of 1:1 methanol:water, resulting in hydrophilic extracts. The extracts from each solvent mixture were combined and filtered. The solvents were removed by evaporation under reduced pressure, and the dry extracts were weighed. The relative quantity of each extract originally present in the macroalgal thalli (hereafter referred to as the 'natural concentration') was calculated on a wet-weight basis and then converted to a volumetric basis for standardization of extracts used in feeding bioassays.

Additional extracts targeting nitrogen-containing compounds were prepared for 23 common subtidal macroalgal species (see Table 1) and the intertidal green alga Cladophora repens. Approximately $100 \mathrm{~g}$ of each species was flash frozen at $-70^{\circ} \mathrm{C}$ and subsequently extracted 3 times with $5 \%$ aqueous $\mathrm{HCl}$ for $24 \mathrm{~h}$ each, then the aqueous portion was decanted, filtered and combined (approximate volume of $1200 \mathrm{ml}$ ). To this extract $600 \mathrm{ml}$ of chloroform was added, and the aqueous layer adjusted to a $\mathrm{pH}$ of 8.0 with a solution of $18 \mathrm{M}$ sodium hydroxide. This sample was thoroughly mixed and allowed to equilibrate, and the chloroform layer was removed. The aqueous layer was partitioned 2 more times with chloroform. The chloroform layers were combined and dried using anhydrous magne- sium sulfate and then concentrated in vacuo. The resultant extract should have quantitatively contained any alkaloids and most other nitrogenous secondary metabolites present in the extracted thallus.

Artificial food preparation. Artificial foods consisted of $2 \%$ alginate containing either $5 \%$ algal powder or $5 \%$ krill as a feeding stimulant (after McClintock \& Baker 1997). For extract bioassays, algal extracts were dissolved in a minimum volume of appropriate solvent carrier and dried onto the algal powder with a rotary evaporator (Hay et al. 1994). The same volume of the solvent carrier was added to powder used for controls and likewise dried. The algal powders were placed into $100 \mathrm{~mm}$ plastic Petri dishes. Cold alginate solution was added to the dishes, mixed thoroughly with the food stimulant, and then gelatinized using cold $1 \mathrm{M}$ $\mathrm{CaCl}_{2}$. This yielded artificial food circles approximately $2 \mathrm{~mm}$ thick that were cut into smaller disks with cork borers for use in fish and amphipod assays. Remnant artificial food was cut into cubes for use in sea star bioassays. The krill powder was mixed into cold alginate solution and then added drop-wise into a solution of cold $1 \mathrm{M} \mathrm{CaCl}_{2}$, where it gelatinized into spheroid pellets approximately 3 to $4 \mathrm{~mm}$ in diameter for use in sea star bioassays.

Bioassay procedures. Sea star bioassays: A bioassay utilizing the common, omnivorous sea star Odontaster validus used methods previously described by McClintock \& Baker (1997). Individuals were offered a small piece of algal thallus (approximately $4 \times 4 \mathrm{~mm}$, the size depending on thallus morphology) or an artificial food pellet (approximately $4 \times 4 \times 2 \mathrm{~mm}$ ) containing either extract or solvent control dried onto Cladophora powder. The thallus fragment or artificial food pellet was placed within the ambulacral groove of a single arm, equidistant between the arm tip and oral opening. Acceptance was recorded when the sea star moved the fragment or pellet to the oral opening and held it there. Rejection was recorded when the sea star dropped the fragment or pellet, or moved it away from the oral opening out of the ambulacral groove or towards the arm tip. Thereafter, the fragment or pellet was removed from the oral opening (if it had been moved there) and the sea star was given a krill powder control pellet. Sample size was 10 to 14 replicates treatment ${ }^{-1}$. With thallus fragments, each replicate consisted of a fragment of an individual alga, with no individual alga used for more than 1 replicate. With extracts, each replicate was an artificial food pellet from the same extract or solvent control preparation. No sea star was used more than once for data that would be statistically compared. Because of a high level of experimental use in this and simultaneous projects, control krill pellets consumed in bioassays were usually sufficient as a maintenance diet. 
Differences between fragments or pellets and corresponding controls were determined using Fisher's exact test of independence (Sokal \& Rohlf 1995). For thallus fragments, the krill pellet that was offered to the sea stars following the fragment served as the control in statistical comparisons. (Note that the krill pellet was always offered second in these no-choice assays.) For extract-treated artificial food pellets, the control was the corresponding solvent-treated control pellets that were offered to a different set of sea stars. In these comparisons, only data from sea stars that accepted the subsequent krill pellet were used to ensure that algal pellet rejection was not due to satiation, although rejection of solvent control pellets was uncommon.

Sea star bioassays conducted during the MarchApril 2000 and February-May 2003 expeditions were performed with sympatric Cladophora repens powder artificial food collected early in each expedition. In the November 2001-January 2002 expedition, dried allopatric C. vagabunda was substituted. Bioassays conducted in November 2001 comparing palatability between the 18 mo old $C$. repens and 4 mo old C. vagabunda material resulted in identical (and complete) acceptance of both.

Fish bioassays: The Antarctic rockfish Notothenia coriiceps was also used for feeding bioassays with thallus fragments and artificial foods. Fish were held in $1 \times 2 \mathrm{~m}$ seawater tables equipped with flowing seawater approximately $0.25 \mathrm{~m}$ in depth during experimental use. Each table was divided into 3 compartments using fine-mesh dividers, with a single fish in each compartment. Fish were also maintained in $2 \mathrm{~m}$ diameter circular holding tanks (3200 l) equipped with running ambient seawater. After capture, the fish were fed a maintenance diet of limpet tissue exclusively offered to them via $20 \mathrm{~cm}$ forceps and they quickly learned to associate items held in such forceps with food.

At least several days of acclimation to the laboratory and feeding regimen elapsed before fish were used in bioassays. In bioassays, 12 fish were offered via $20 \mathrm{~cm}$ forceps either a piece of algal thallus (approx. $20 \times$ $20 \mathrm{~mm}$, but variable depending on thallus morphology) or an artificial food pellet (a disk, $20 \mathrm{~mm}$ diameter $\times$ approx. $2 \mathrm{~mm}$ ) containing extract dried onto algal powder. These food items were large enough to require the fish to mouth them before swallowing, although they do not literally 'chew' any of their food items. Five minutes after being presented with the experimental disk, each fish was given a control disk consisting of $5 \%$ algal powder in $2 \%$ alginate. Fish were offered no more than 3 sets of different treatments (thallus or extract disk) and appropriate controls per day, with at least 5 to 6 h elapsing between sets. No fish was offered more than 1 replicate set of foods that would be statistically compared with each other. With thallus fragments, each replicate consisted of a fragment of an individual alga, with no individual alga used for more than 1 replicate. With extracts, each replicate was an artificial food pellet from the same extract or solvent control preparation. In thallus bioassays, the control disk was a non-solvent-treated algal powder alginate disk. In extract bioassays, the control disk was the appropriate solvent-treated algal powder control. Acceptance was recorded when the fish ate a pellet and did not regurgitate it. Rejection was recorded when the fish took the disk into its mouth and subsequently spat it out. Significance of difference between thallus fragments or extract disks and corresponding controls was determined using Fisher's exact test of independence (Sokal \& Rohlf 1995).

Fish bioassays conducted during the March-April 2000 expedition were performed with Cladophora repens powder artificial food. However, the fish used during the November 2001-January 2002 expedition would not reliably consume the allopatric $C$. vagabunda, so Palmaria decipiens powder was substituted.

Technical problems prevented us from performing a full suite of fish bioassays. Microscopic air bubbles resulting from gas super-saturation in the station seawater system resulted in very rapid, mass fish kills in the aquarium tanks several times, and appropriate tanks were not available during the 2003 expedition.

Amphipod bioassays: The herbivorous amphipod Gondogeneia antarctica was used in extract bioassays with artificial foods only. Before and after assays, amphipods were placed in 2 or 41 plastic bottles — with large holes, covered by plastic window screening to allow free exchange of seawater-and held in flowthrough seawater aquaria. The maintenance diet was primarily leftover control Cladophora powder alginate foods, but thallus fragments of palatable macroalgae were often also present. Unlike the sea star and fish bioassays, this was a feeding preference assay modeled after the recommendations of Peterson \& Renaud (1989): 20 haphazardly selected amphipods were placed into each of ten $250 \mathrm{ml}$ sealed bottles floating in flowthrough seawater aquaria with 1 artificial food pellet containing extract dried onto an algal powder disk and 1 artificial food pellet containing only solvent-control algal powder in each bottle. Disks were $10 \mathrm{~mm}$ diameter $\times$ approximately $2 \mathrm{~mm}$ thick. Identical disks that were pairs of the disks available to the amphipods (cut from spots immediately adjacent to them in the gelatinized alginate-powder mix) were placed into paired, identical bottles but without amphipods. Feeding preference was determined by calculating wet mass change between the paired extract and control disks in the 2 bottles over the course of the experiment (usually 8 to $12 \mathrm{~h}$ ). Signifi- 
cance of differences between the changes in the 10 paired controls and 10 paired extract treatments were compared by a Wilcoxon signed ranks test (designed for related samples) using SPSS software. The algal powder was Cladophora spp. as described in sea star bioassays. Bioassays conducted in November 2001 comparing palatability between the 18 mo old $C$. repens and 4 mo old C. vagabunda material showed that both were readily consumed, but with a slight yet significant $(p<0.05)$ preference for foods containing the fresher $C$. vagabunda.

Thallus toughness measurements. The force required to puncture macroalgal thalli was measured using a penetrometer, as described by Duffy \& Hay (1991). All measurements were performed during November and December 2001. The force necessary to puncture a thallus was measured in 3 different places on each individual, and the mean of these 3 measurements was used as a single sample for statistical analysis. Sample size was 10 individuals of each species amenable to the technique that could be collected in sufficient numbers during this time period. Statistical analysis of differences between species utilized square-root-transformed data and was done by 1-way ANOVA with a Ryan-Eniot-Gabriel-Welsch (REGWQ) post hoc analysis using SPSS software. Analysis of differences between brown and red macroalgal species overall was done by a $t$-test using SPSS software with the mean for each species constituting a single sample.

Selective staining for nitrogenous secondary metabolites. Acid extracts were examined for the presence of alkaloids and other nitrogenous secondary metabolites by thin-layer chromatography (TLC). A number of standards were also examined to establish the behavior of well-known groups of alkaloids. These included vitamin B12, discorhabdin G, kanamycin and cyclosporin A. Non-alkaloid standards included chloramphenicol, inosine, and 3-hydroxy-kyneurinine. The samples and standards were diluted to a concentration of $2 \mathrm{mg} \mathrm{ml}^{-1}$. These were then spotted onto normal-phase (silica) and reverse-phase (C-18) TLC plates. Those applied to reverse-phase plates were developed with methanol, 75\% methanol:water and 50\% methanol:water. Those applied to normalphase plates were developed with mixtures of hexane and ethyl acetate including 100\% hexane, 90\% hexane, $75 \%$ hexane, $50 \%$ hexane, $25 \%$ hexane and $100 \%$ ethyl acetate. After drying, compounds on the TLC plates were visualized by 4 methods: UV light, phosphomolybdic acid (PMA), ninhydrin, and Dragendorff's solution. UV light visualizes organic compounds that absorb UV radiation. PMA visualizes most organic compounds after heating. $2 \%$ ninhydrin in ethanol is used to stain primary and secondary amino-acid functional groups. Spots stained with
Dragendorff's solution would selectively indicate the presence of alkaloids.

Compounds identified by Dragendorff's solution were subsequently isolated by preparative TLC. Structural determination was achieved by a combination of GC/MS and ${ }^{1} \mathrm{H}$ NMR spectroscopy.

\section{RESULTS}

\section{Thallus bioassays}

Overall, 35 non-encrusting macroalgal species were utilized in at least 1 of the thallus bioassays (Fig. 1, Table 1). This represents $100 \%$ of the non-encrusting, subtidal macroalgal species collected from the study area that were available in sufficient quantities for bioassays and well over $99 \%$ of the total standing biomass present in the study area. Geminocarpus geminatus and Chordaria linearis were too small for thallus assays with fish. Four red algal species (Fig. 1, Table 1) were not used in bioassays with fish because of logistical constraints noted in 'Materials and methods'.

Overall, $22(63 \%)$ of the 35 macroalgal species offered to sea stars and $24(83 \%)$ of the 29 macroalgal species offered to fish in thallus bioassays were rejected (Fig. 1, Table 1). All of the dominant overstory brown macroalgae (Desmarestia anceps, D. antarctica, D. menziesii, Himantothallus grandifolius, and Cystosphaera jacquinotii) were unpalatable to both sea stars and fish in thallus bioassays.

\section{Extract bioassays}

Natural concentrations for each extract as well as wet:dry weight and wet-weight:volume ratios are given in Table 2. Both lipophilic and hydrophilic extracts added to artificial foods were commonly unpalatable to sea stars, fish, and amphipods (Figs. 2 to 4). Extract bioassays against sea stars were performed with all macroalgal species that were unpalatable to sea stars as thallus except for Chordaria linearis, which is small and relatively rare, so that insufficient biomass was available for extraction. Of the remaining 21 species, $16(76 \%)$ were unpalatable to sea stars as lipophilic extracts, hydrophilic extracts, or both (Fig. 2, Table 1). At least 1 extract type of all the dominant overstory brown macroalgae was unpalatable to the sea stars.

Extract bioassays against fish were performed with at least 1 extract type in 17 of the 24 macroalgal species that were unpalatable to fish as thallus. Of these, $9(53 \%)$ were unpalatable as either lipophilic or hydrophilic extracts (Fig. 3, Table 1). However, of the other 

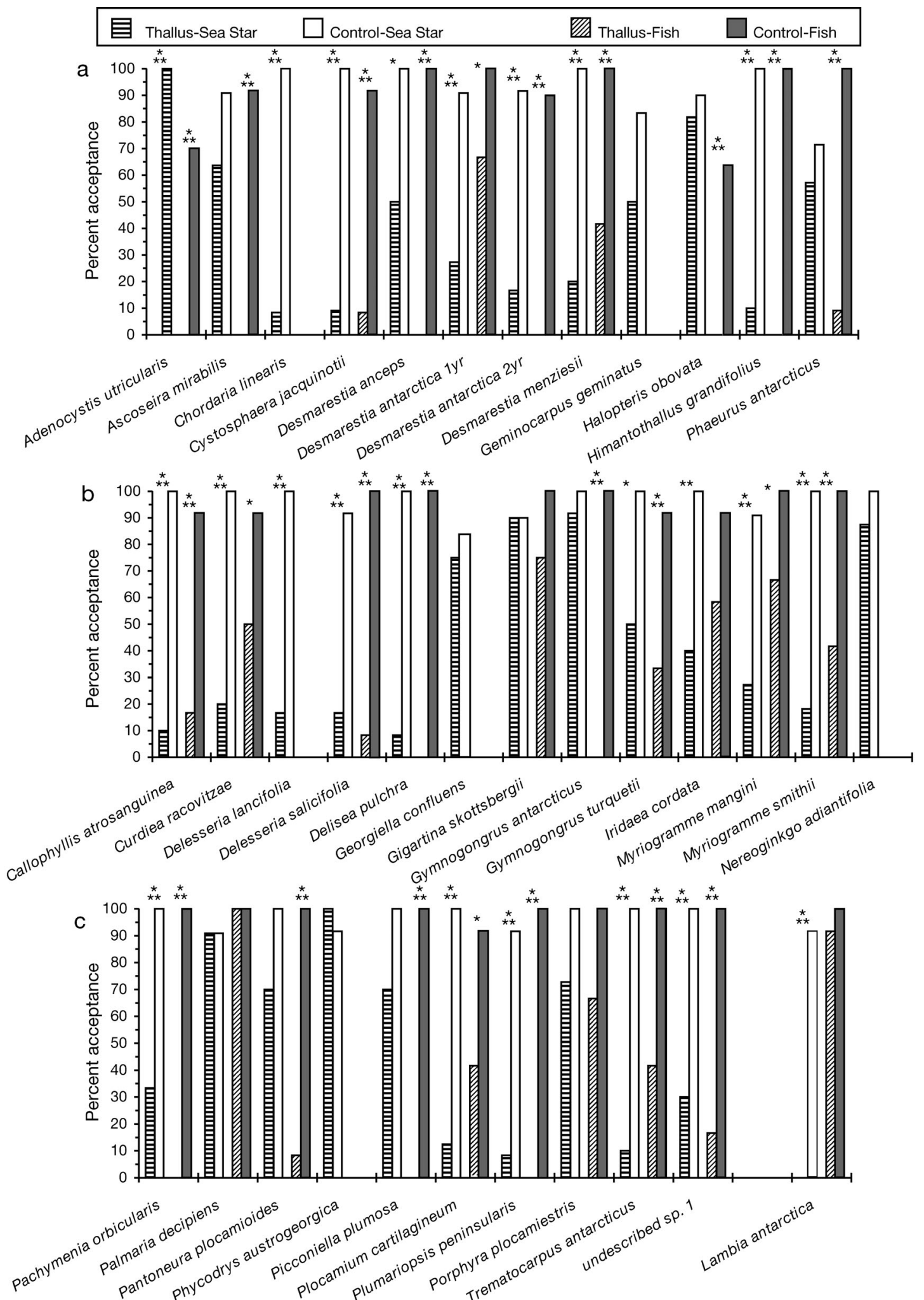

Fig. 1. Odontaster validus and Notothenia coriiceps. Results of bioassays offering pieces of macroalgal thallus to the sea star $O$. validus and the fish $N$. coriiceps. (a) Brown algae (Class Phaeophyceae); (b) red algae (Class Rhodophyceae) part 1 ; (c) red algae part 2 and the green alga Lambia antarctica (Class Ulvophyceae). Asterisks indicate significant difference between thallus and control (Fisher's exact test); ${ }^{*} \mathrm{p} \leq 0.05,{ }^{* *} \mathrm{p} \leq 0.01, * * * \mathrm{p} \leq 0.005$ 
Table 1. Summary of feeding bioassay, thallus toughness, and nutritional data. $\mathrm{St}=$ sea stars, Fi $=$ fish, Am = amphipods, R= thallus or at least 1 extract type rejected in bioassays, a = thallus or both extract types accepted in bioassays, (a) = only 1 extract type tested in bioassays and accepted, Tgh rank $=$ (toughness rank) rank of force required to puncture thallus with $1=$ lowest and $30=$ highest, nutritional rank = rank order of nutritional data from Peters (2004) and Peters et al. (2005) with $1=$ lowest and $34=$ highest. Nutritional categories: Pro $=$ protein, Car $=$ carbohydrate, Lip $=$ lipid, Ash $=$ ash, C:N = carbon:nitrogen atomic ratio. For simplicity, percentage of elemental carbon and nitrogen are not presented in this table; overall \% $\mathrm{C}$ varied little and \% $\mathrm{N}$ was closely (and inversely) correlated with the elemental C:N ratio (Peters 2004, Peters et al. 2005)

\begin{tabular}{|c|c|c|c|c|c|c|c|c|c|c|c|}
\hline \multirow[t]{2}{*}{ Species } & \multicolumn{2}{|c|}{ Thallus } & \multicolumn{3}{|c|}{ Extract } & \multirow{2}{*}{$\begin{array}{l}\text { Tgh } \\
\text { rank }\end{array}$} & \multicolumn{5}{|c|}{ Nutritional rank } \\
\hline & St & $\mathrm{Fi}$ & St & $\mathrm{Fi}$ & Am & & Pro & Car & Lip & Ash & $\mathrm{C}: \mathrm{N}$ \\
\hline \multicolumn{12}{|l|}{ Class Phaeophyceae (brown algae) } \\
\hline Adenocystis utricularis $^{\mathrm{a}}$ (Bory) Skottsberg & $\mathrm{R}$ & $\mathrm{R}$ & $\mathrm{R}$ & (a) & $\mathrm{R}$ & 14 & 21 & 10 & 24 & 32 & 26 \\
\hline Ascoseira mirabilis ${ }^{\mathrm{a}}$ Skottsberg & $\mathrm{a}$ & $\mathrm{R}$ & & (a) & a & 28 & 8 & 7 & 30 & 19 & 29 \\
\hline Chordaria linearis (Hooker f. \& Harvey) Cotton & $\mathrm{R}$ & & & & & & & & & & \\
\hline Cystosphaera jacquinotii ${ }^{\text {a }}$ (Montagne) Skottsberg & $\mathrm{R}$ & $\mathrm{R}$ & $\mathrm{R}$ & $\mathrm{R}^{\mathrm{b}}$ & $\mathrm{R}$ & 23 & 28 & 9 & 15 & 6 & 31 \\
\hline Desmarestia anceps ${ }^{\mathrm{a}}$ Montagne & $\mathrm{R}$ & $\mathrm{R}$ & $\mathrm{R}$ & $\mathrm{R}$ & $\mathrm{R}$ & 11 & 23 & 3 & 12 & 5 & 25 \\
\hline Desmarestia antarctica $^{\text {a }}$ Moe \& Silva, first year & $\mathrm{R}$ & $\mathrm{R}$ & $\mathrm{R}$ & (a) & a & & 16 & 4 & 21 & 23 & 19 \\
\hline D. antarctica, second year & $\mathrm{R}$ & $\mathrm{R}$ & $\mathrm{R}$ & & $\mathrm{R}$ & 25 & 12 & 5 & 28 & 25 & 24 \\
\hline Desmarestia menziesii ${ }^{\text {a }} \mathrm{J}$ Agardh & $\mathrm{R}$ & $\mathrm{R}$ & $\mathrm{R}$ & $\mathrm{R}$ & $\mathrm{R}$ & 13 & 30 & 8 & 34 & 2 & 23 \\
\hline Geminocarpus geminatus (Hooker f. \& Harvey) Skottsb. & a & & & & & & & & & & \\
\hline Halopteris obovata (Hooker f. \& Harvey) Sauvageau & $\mathrm{a}$ & $\mathrm{R}$ & & & a & 12 & 4 & 11 & 14 & 33 & \\
\hline Himantothallus grandifolius $^{\mathrm{a}}$ (A \& E Gepp) Zinova & $\mathrm{R}$ & $\mathrm{R}$ & $\mathrm{R}$ & $\mathrm{R}$ & $\mathrm{R}$ & 26 & 29 & 2 & 11 & 3 & 30 \\
\hline Phaeurus antarcticus ${ }^{\mathrm{a}}$ Skottsberg & $\mathrm{a}$ & $\mathrm{R}$ & & & $\mathrm{R}$ & 16 & 32 & 1 & 33 & 24 & 22 \\
\hline \multicolumn{12}{|l|}{ Class Rhodophyceae (red algae) } \\
\hline Callophyllis atrosanguinea (Hooker f. \& Harvey) Hariot & $\mathrm{R}$ & $\mathrm{R}$ & $\mathrm{R}$ & (a) & a & 17 & 6 & 20 & 1 & 26 & 7 \\
\hline Curdiea racovitzae ${ }^{\mathrm{a}}$ Hariot & $\mathrm{R}$ & $\mathrm{R}$ & $\mathrm{R}$ & & a & 27 & 33 & 34 & 29 & 1 & 10 \\
\hline Delesseria lancifolia (Hooker f.) J Agardh & $\mathrm{R}$ & & a & & $\mathrm{R}$ & & 24 & 29 & 6 & 10 & \\
\hline Delesseria salicifolia Reinsch & $\mathrm{R}$ & $\mathrm{R}$ & $\mathrm{R}$ & $\mathrm{R}$ & $\mathrm{R}$ & 2 & 15 & 22 & 16 & 31 & 5 \\
\hline Delisea pulchra ${ }^{a}$ (Grenville) Montagne & $\mathrm{R}$ & $\mathrm{R}$ & $\mathrm{R}$ & & $\mathrm{R}$ & 4 & 7 & 19 & 27 & 12 & 18 \\
\hline Georgiella confluens (Reinsch) Kylin & $\mathrm{a}$ & & & & & 15 & 31 & 24 & 18 & 8 & 17 \\
\hline Gigartina skottsbergii ${ }^{\text {a }}$ Setchell \& Gardner & $\mathrm{a}$ & $\mathrm{a}$ & & & & 30 & 2 & 33 & 3 & 4 & 28 \\
\hline Gymnogongrus antarcticus ${ }^{\mathrm{a}}$ Skottsberg & $\mathrm{a}$ & $\mathrm{R}$ & & & a & 22 & 17 & 14 & 5 & 30 & 11 \\
\hline Gymnogongrus turquetii ${ }^{\mathrm{a}}$ Hariot & $\mathrm{R}$ & $\mathrm{R}$ & $\mathrm{R}$ & $\mathrm{R}$ & $\mathrm{R}$ & 19 & 13 & 26 & 7 & 14 & 6 \\
\hline Iridaea cordata ${ }^{\mathrm{a}}$ (Turner) Bory & $\mathrm{R}$ & a & $\mathrm{R}$ & & $\mathrm{R}$ & 24 & 14 & 31 & 9 & 7 & 20 \\
\hline Myriogramme mangini ${ }^{\mathrm{a}}$ (Gain) Skottsberg & $\mathrm{R}$ & $\mathrm{R}$ & $\mathrm{R}$ & & a & 20 & 27 & 25 & 23 & 16 & 9 \\
\hline Myriogramme smithii ${ }^{\text {a }}$ (Hooker f. \& Harvey) Kylin & $\mathrm{R}$ & $\mathrm{R}$ & $\mathrm{R}$ & $\mathrm{R}$ & $\mathrm{R}$ & 7 & 26 & 13 & 22 & 29 & 3 \\
\hline Nereoginkgo adiantifolia Kylin & $\mathrm{a}$ & & & & & 18 & 3 & 15 & 13 & 27 & 15 \\
\hline Pachymenia orbicularis (Zanardini) Setchell \& Gardner & $\mathrm{R}$ & $\mathrm{R}$ & $\mathrm{a}$ & & a & 29 & 1 & 30 & 2 & 11 & 27 \\
\hline Palmaria decipiens ${ }^{\mathrm{a}}$ (Reinsch) Ricker & $\mathrm{a}$ & $\mathrm{a}$ & & & & 10 & 34 & 27 & 26 & 15 & 1 \\
\hline Pantoneura plocamioides ${ }^{\mathrm{a}}$ Kylin & $\mathrm{a}$ & $\mathrm{R}$ & & a & a & 5 & 18 & 21 & 10 & 17 & 16 \\
\hline Phycodrys austrogeorgica Skottsberg & $\mathrm{a}$ & & & & & & 9 & 18 & 17 & 20 & 2 \\
\hline Picconiella plumosa ${ }^{\mathrm{a}}$ (Kylin) De Toni & a & $\mathrm{R}$ & & (a) & $\mathrm{R}$ & 1 & 22 & 17 & 25 & 28 & 12 \\
\hline Plocamium cartilagineum ${ }^{\mathrm{a}}$ (Linnaeus) Dixon & $\mathrm{R}$ & $\mathrm{R}$ & $\mathrm{R}$ & $\mathrm{R}$ & $\mathrm{R}$ & 6 & 10 & 12 & 32 & 18 & 13 \\
\hline Plumariopsis peninsularis Moe \& Silva & $\mathrm{R}$ & $\mathrm{R}$ & $\mathrm{R}$ & (a) & $\mathrm{R}$ & 9 & 25 & 16 & 19 & 21 & 8 \\
\hline Porphyra plocamiestris Ricker & $\mathrm{a}$ & $\mathrm{a}$ & & & & & 11 & 32 & 20 & 9 & \\
\hline Trematocarpus antarcticus ${ }^{\mathrm{a}}$ Fredericq, Moe \& Ramírez & $\mathrm{R}$ & $\mathrm{R}$ & $\mathrm{a}$ & a & a & 8 & 20 & 23 & 8 & 13 & 4 \\
\hline Undescribed sp. $1^{\mathrm{a}}$ & $\mathrm{R}$ & $\mathrm{R}$ & $\mathrm{a}$ & $\mathrm{R}$ & $\mathrm{R}$ & 21 & 5 & 28 & 4 & 22 & 14 \\
\hline Class Ulvophyceae (green algae) & & & & & & & & & & & \\
\hline Lambia antarctica ${ }^{\mathrm{a}}$ (Skottsberg) Delépine & $\mathrm{R}$ & $\mathrm{a}$ & $\mathrm{a}$ & & a & 3 & 19 & 6 & 31 & 34 & 21 \\
\hline
\end{tabular}

8 unpalatable species used in extract assays, only 3 were assayed as both lipophilic and hydrophilic extracts because of logistical constraints. One extract type of all the dominant overstory brown macroalgae was unpalatable, except for Desmarestia antarctica. Only the lipophilic extract of first-year $D$. antarctica was assayed, and this was quite palatable to the fish (Fig. 3a).
If either sea stars or fish rejected thallus material of a macroalgal species, then extract bioassays of this species were performed using amphipods. Of 27 such macroalgal species, 17 (63\%) were significantly less preferred by amphipods compared with controls when presented as lipophilic extracts, hydrophilic extracts, or both (Fig. 4, Table 1). At least 1 extract type of all the dominant overstory species was significantly less pre- 
ferred than controls except in Desmarestia antarctica. Only hydrophilic extracts of second-year $D$. antarctica were less preferred than controls, while both extract types in first-year thalli were preferred over controls (Fig. 4a). This was not unusual, as extracts from many of the macroalgal species were preferred to controls (Fig. 4). Indeed, when lipophilic or hydrophilic extracts of Cladophora repens were bioassayed in artificial foods using C. repens powder as the feeding stimulant, the extracts were also significantly preferred over controls ( $p=0.005$ in both extract types). Because the artificial foods were soaking in seawater during the course of the assays, it is possible that false-negative results could have occurred, particularly with hydrophilic extracts, because of leaching of defensive compounds. However, it is of note that of 28 hydrophilic extracts (Fig. 4) 20 (71\%) were either significantly more or less preferred than controls, suggesting that many if not most compounds remained within the artificial foods long enough to produce significant responses.

To check for potential extraction artifacts that might cause an otherwise palatable extract to be artificially unpalatable, some extracts were prepared from macroalgae palatable as thallus and tested in bioassays with sea stars and/or amphipods (data not shown). In all 16 such assays, the extracts were palatable.

\section{Thallus toughness}

The mean force required to puncture macroalgal thalli ranged from $<1 \mathrm{~N}$ in Picconiella plumosa to $>20 \mathrm{~N}$ in Gigartina skottsbergii (Fig. 5). Although ANOVA indicated that there were marked and significant differences between individual species $\left(F_{29,299}=\right.$ 91.731, p < 0.0005), no clear patterns between taxonomic groups or palatable and unpalatable species were apparent. Overall, the brown macroalgal species were not significantly tougher than the red species (8.1 vs. $6.4 \mathrm{~N}$ respectively; $t_{27}=0.713, \mathrm{p}=0.482$ ).

\section{Selective staining for nitrogenous secondary metabolites}

All of the nitrogenous standards used could be visualized by ninhydrin and/ or Dragendorff's solution. Although many compounds were present in TLC preparations of the acid extracts as visualized by the unspecific stain PMA and by UV light, no compounds in the extracts were stained by ninhydrin. Two compounds from Delisea pulchra stained very lightly with Dragendorff's solution. They were determined to be halogenated $\gamma$-lactones previously identified from $D$. pulchra (as $D$. fimbrata; Kazlauskas et al. 1977) that had slight crossreactivity with the stain but did not contain nitrogen.

\section{DISCUSSION}

\section{Bioassay animals}

The sea star Odontaster validus is an omnivore that feeds on macroalgae as well as on a variety of benthic invertebrates (Dearborn 1977, McClintock 1994). Although we are not aware of quantitative studies of its feeding preferences in communities where it co-

Table 2. Volumetric extract yields (defined as the 'natural concentration' of an extract) expressed as mg dry extract per $\mathrm{ml}$ wet thallus. $\mathrm{ww}: \mathrm{dw}=$ wet weight to dry weight ratio. ww:vol $=$ wet weight to volume ratio $(\mathrm{mg}$ wet thallus per $\mathrm{ml}$ wet thallus)

\begin{tabular}{|c|c|c|c|c|}
\hline \multirow[t]{2}{*}{ Species } & \multicolumn{2}{|c|}{ Volumetric extract yields } & \multicolumn{2}{|c|}{ Ratios } \\
\hline & Lipophilic & Hydrophilic & ww:dw & ww:vol \\
\hline \multicolumn{5}{|l|}{ Class Phaeophyceae } \\
\hline Adenocystis utricularis & 40.0 & 11.2 & 8.93 & 0.92 \\
\hline Ascoseira mirabilis & 45.1 & 6.1 & 6.81 & 1.01 \\
\hline Cystosphaera jacquinotii & 89.4 & 25.6 & 6.40 & 1.03 \\
\hline Desmarestia anceps & 19.1 & 54.1 & 5.06 & 1.05 \\
\hline Desmarestia antarctica, first year & ar $\quad 9.4$ & 52.5 & 9.63 & 1.02 \\
\hline D. antarctica, second year & 31.7 & 16.5 & 5.07 & 1.05 \\
\hline Desmarestia menziesii & 28.3 & 65.6 & 5.08 & 1.03 \\
\hline Halopteris obovata & 33.1 & 6.7 & 4.52 & 0.89 \\
\hline Himantothallus grandifolius & 13.6 & 73.2 & 8.11 & 0.97 \\
\hline Phaeurus antarcticus & 48.1 & 8.0 & 8.10 & 1.06 \\
\hline \multicolumn{5}{|l|}{ Class Rhodophyceae } \\
\hline Callophyllis atrosanguinea & 42.1 & 7.5 & 6.89 & 1.05 \\
\hline Curdiea racovitzae & 50.6 & 17.5 & 4.63 & 0.91 \\
\hline Delesseria lancifolia & 45.8 & 10.7 & 5.69 & 1.06 \\
\hline Delesseria salicifolia & 12.0 & 43.4 & 5.01 & 0.81 \\
\hline Delisea pulchra & 54.4 & 6.7 & 6.55 & 1.02 \\
\hline Gymnogongrus antarcticus & 40.2 & 3.9 & 3.96 & 0.92 \\
\hline Gymnogongrus turquetii & 46.0 & 7.1 & 5.80 & 1.04 \\
\hline Iridaea cordata & 10.4 & 57.9 & 3.63 & 1.11 \\
\hline Myriogramme mangini & 19.9 & 82.1 & 3.30 & 1.12 \\
\hline Myriogramme smithii & 16.1 & 56.3 & 5.00 & 0.99 \\
\hline Pachymenia orbicularis & 31.5 & 7.0 & 6.16 & 1.00 \\
\hline Pantoneura plocamioides & 40.6 & 14.0 & 4.41 & 1.11 \\
\hline Picconiella plumosa & 41.1 & 6.7 & 5.68 & 1.06 \\
\hline Plocamium cartilagineum & 29.0 & 44.1 & 5.04 & 1.00 \\
\hline Plumariopsis peninsularis & 47.3 & 10.7 & 5.55 & 1.04 \\
\hline Trematocarpus antarcticus & 12.3 & 52.6 & 6.17 & 1.02 \\
\hline Undescribed sp. 1 & 48.1 & 7.0 & 5.28 & 1.09 \\
\hline \multicolumn{5}{|l|}{ Class Ulvophyceae } \\
\hline Lambia antarctica & 29.5 & 1.9 & 13.73 & 1.08 \\
\hline
\end{tabular}



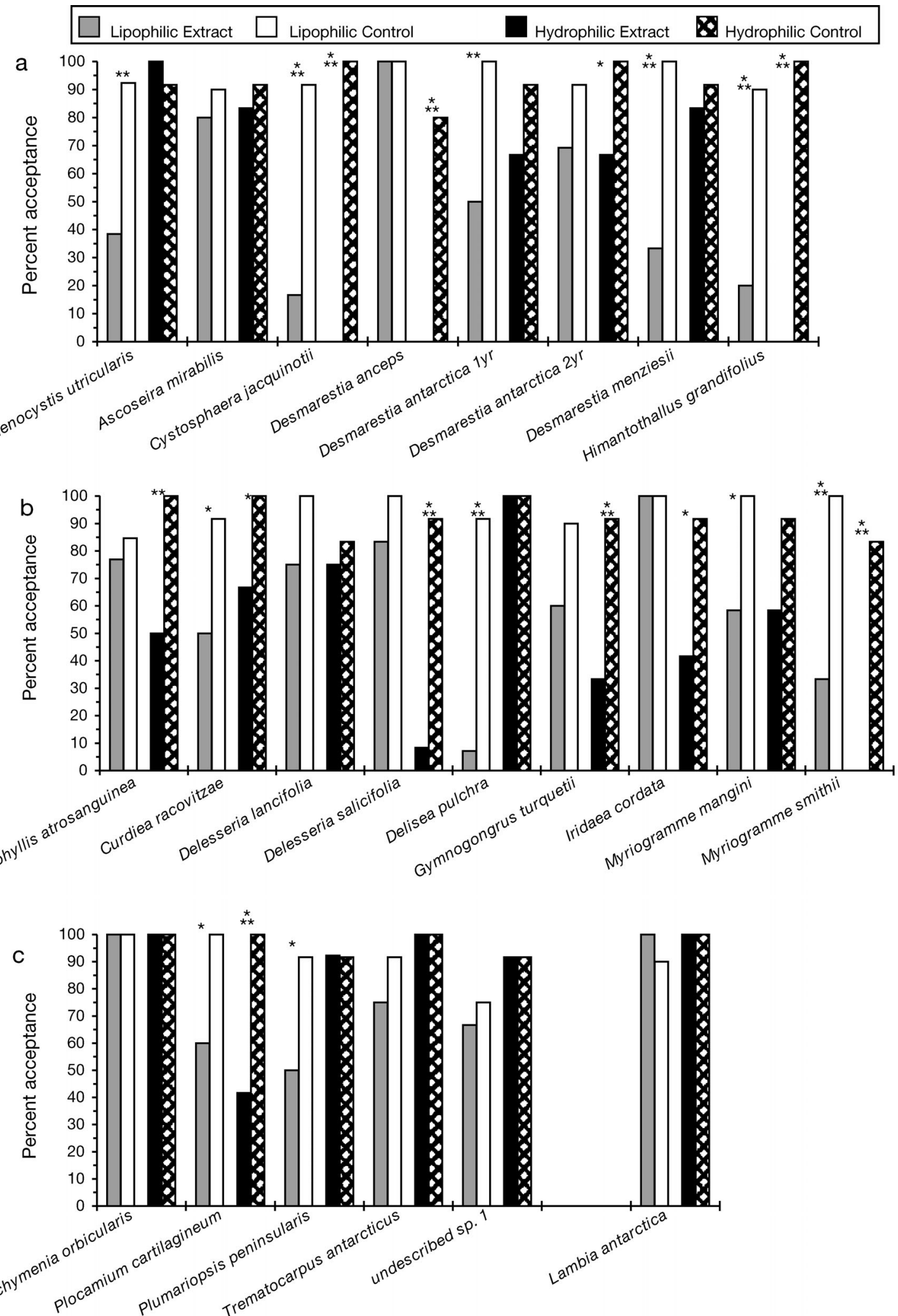

Fig. 2. Odontaster validus. Results of bioassays offering artificial foods containing lipophilic or hydrophilic algal extracts to sea stars. (a) Brown algae (Class Phaeophyceae). (b) Red algae (Class Rhodophyceae) part 1. (c) Red algae part 2 and the green alga Lambia antarctica (Class Ulvophyceae). Asterisks indicate significant difference between extract and control (Fisher's exact test); ${ }^{*} \mathrm{p} \leq 0.05,{ }^{*} \mathrm{p} \leq 0.01, * * * \mathrm{p} \leq 0.005$ 
occurs with macroalgae, it is very abundant in macroalgal communities near Palmer Station and is commonly seen on macroalgae (authors' pers. obs.). Macroalgae form an important part of the diet of the omnivorous Antarctic rockfish Notothenia coriiceps (up to $96 \%$ of stomach contents; mean $39 \%$ of contents; Iken et al. 1997, 1999 and references therein). Although some of the consumed macroalgae may be accidentally ingested when feeding on mesofauna, much is clearly the result of selective grazing on macroalgae (Barrera-Oro \& Casaux 1990, Iken et al. 1997, 1999). N. coriiceps is the only abundant demersal fish observed in the study area (authors' pers. obs.). Gondogeneia antarctica is the major herbivorous amphipod in many locations along the Antarctic Peninsula, consuming both diatoms and macroalgae (Richardson 1977, De Broyer et al. 1988, Iken et al. 1998, Momo et al. 1998, Jazdzewski et al 2001). It is one of the most abundant amphipods observed near Palmer Station (Y. Huang unpubl. obs., authors' pers. obs.). Although they readily consume macroalgae in laboratory aquaria, because the amphipods preferentially feed at edges of disks or thallus fragments, the choice bioassay would not be suited for use with thallus fragments, unless the algal species used were closely matched in geometry and thickness. However, feeding preference experiments with $G$. antarctica performed with finely ground, lyophilized macroalgal

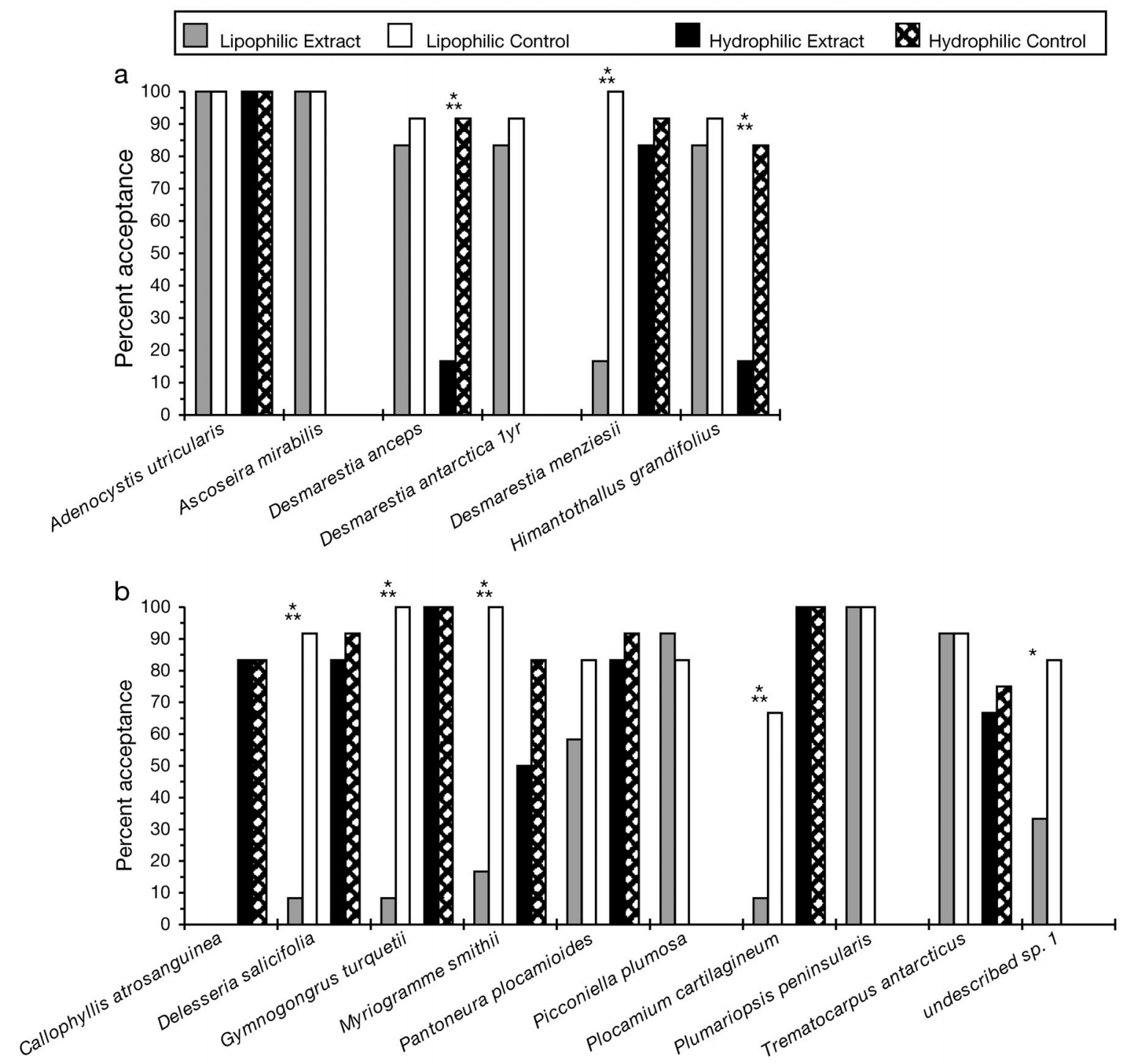

Fig. 3. Notothenia coriiceps. Results of bioassays offering artificial foods containing lipophilic or hydrophilic algal extracts to fish. (a) Brown algae (Class Phaeophyceae). (b) Red algae (Class Rhodophyceae). Asterisks indicate significant difference between extract and control (Fisher's exact test) $;{ }^{*} \mathrm{p} \leq 0.05, * * * \mathrm{p} \leq 0.005$ 

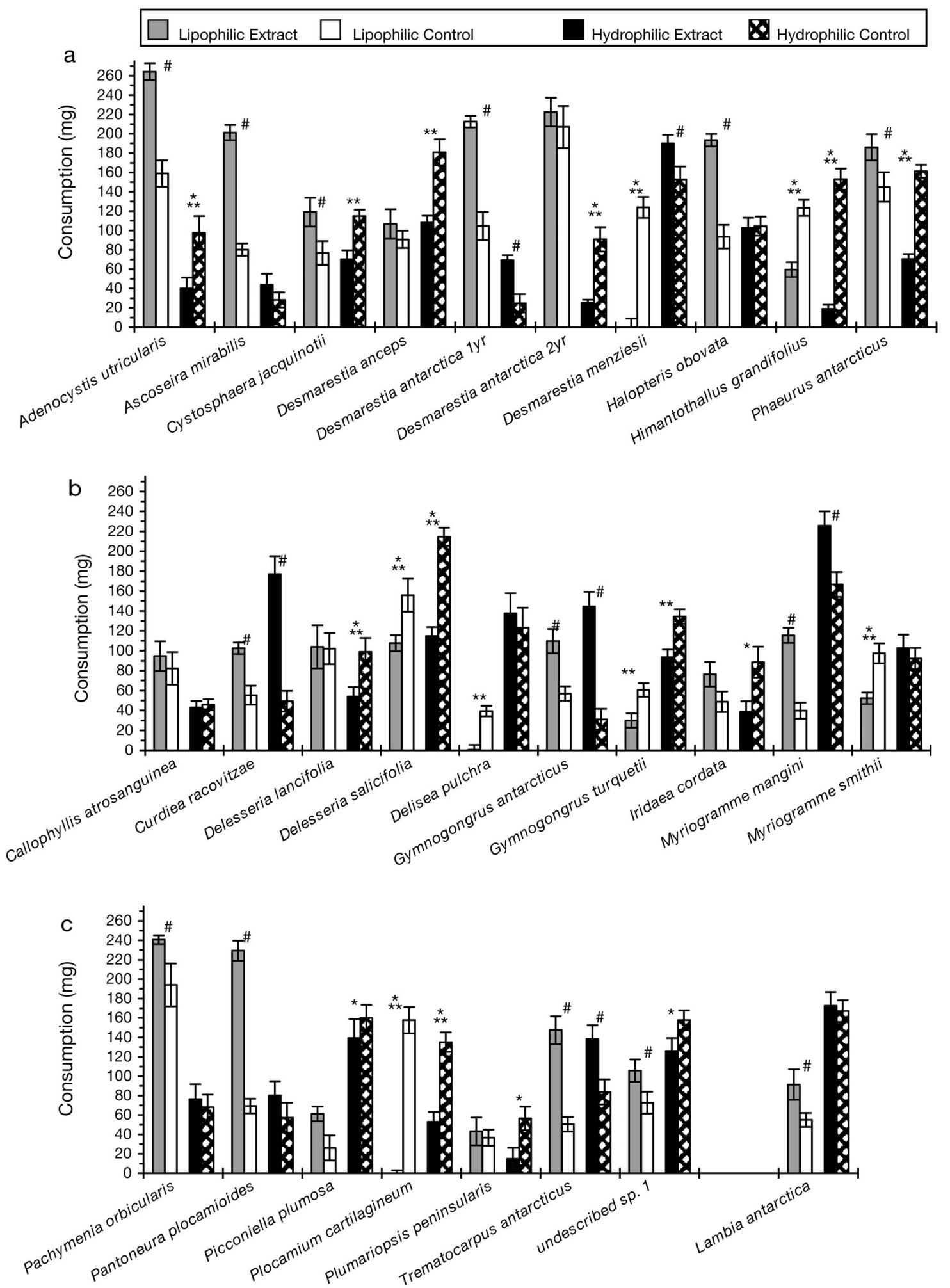

Fig. 4. Gondogeneia antarctica. Results of bioassays offering artificial foods containing lipophilic or hydrophilic algal extracts to amphipods. Means \pm standard error of mean. (a) Brown algae (Class Phaeophyceae). (b) Red algae (Class Rhodophyceae) part 1. (c) Red algae part 2 and the green alga Lambia antarctica (Class Ulvophyceae). Asterisks indicate significant difference between extract and control (Wilcoxon signed ranks test) with controls significantly preferred to extracts; ${ }^{*} \mathrm{p} \leq 0.05, * * \mathrm{p} \leq 0.01$, $\star * * p=0.005$. Pound symbols (\#) indicate significant differences $(\mathrm{p} \leq 0.05)$ between extract and control (Wilcoxon signed ranks test), with extracts significantly preferred to controls ( $p$ levels ranged down to $p=0.005$, but for simplicity only 1 symbol is used) 
thalli of 8 species presented in an alginate matrix as described above closely matched results of our extract bioassays (Y. Huang et al. unpubl. obs.).

Anyone familiar with Antarctic benthic communities would likely question why the sea urchin Sterechinus neumayeri was not used as a bioassay organism. Unfortunately, just as we observed when attempting to use it as a bioassay organism in McMurdo Sound, Antarctica (Amsler et al. 1998), S. neumayeri would not consistently eat anything in the laboratory aquaria. With the McMurdo Sound animals we developed a phagostimulation bioassay, but this probably would not have produced meaningful results in those experiments had the rejection responses not been very rapid, and we did not feel that it was appropriate for the present study, which looked at responses to a wide range of potentially palatable and unpalatable items.

\section{Palatability and defenses}

The 35 macroalgal species examined in the present study include all brown algal species reported as ecologically dominant in Antarctica as well as all of the most common non-encrusting red algal species found along the Antarctic Peninsula. Of the 120 to 130 macroalgal species known from Antarctica, at least 30 are reported to be either crustose, restricted to the intertidal, or endophytic (Wiencke \& Clayton 2002). Consequently, the present study represents not only all non-encrusting subtidal species collected in the study area that were present in sufficient quantities for assays (35 of approximately 41), but over a third of the non-encrusting, subtidal macroalgal flora of Antarctica as a whole.

A majority of the macroalgal species examined were unpalatable to Odontaster validus and Notothenia coriiceps. In the context of benthic communities in the study area, palatable macroalgae are uncommon. All of the brown macroalgae that dominate the communities in terms of standing biomass plus most of the more abundant red macroalgae in the study area as reported by DeLaca \& Lipps (1976) and Amsler et al. (1995) were unpalatable.

Chemical defenses appear to be very important in determining the palatability of macroalgal species. Our 2 extraction methods target a suite of non-polar and polar compounds, and crude extracts present a mixture of primary and secondary metabolites. Since all structural elements of the algae are factored out, it is reasonable to interpret rejections in crude-extract feeding bioassays as an indication of a chemically based defense mechanism, even though we know the individual compounds responsible for the observed reactions in only a few instances (Ankisetty et al. 2004). Against sea stars, $48 \%$ of the macroalgal species

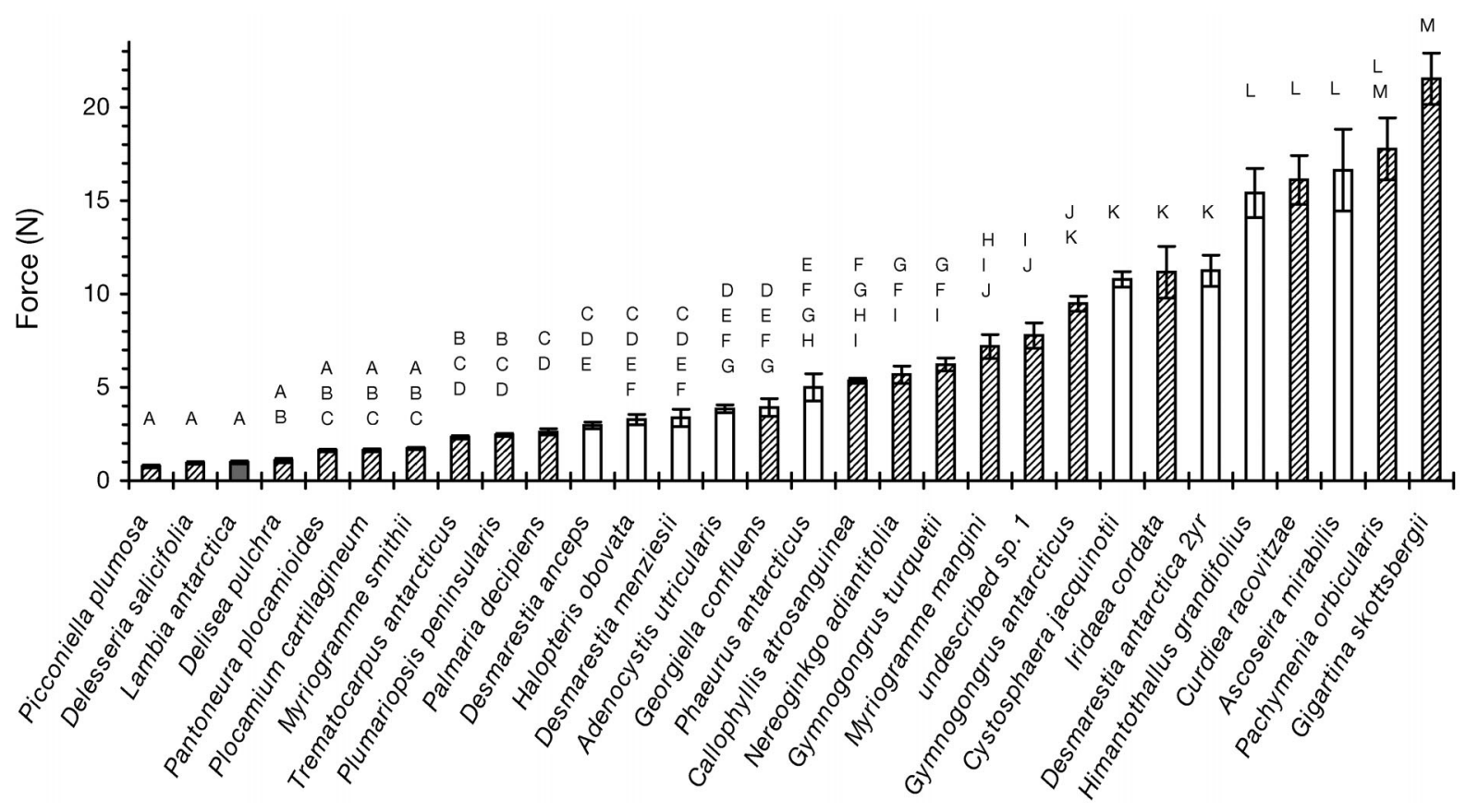

Fig. 5. Results of penetrometry measurements of macroalgal thallus toughness. Mean force required to puncture thallus \pm standard error of mean. Open bars indicate brown macroalgae, hatched bars indicate red macroalgae, and the gray bar indicates the single green macroalga Lambia antarctica. Results of REGWQ post hoc statistical analysis are presented as letters above bars. Bars with the same letter are not significantly different $(p=0.05)$ 
examined were chemically defended $(63 \%$ of the species unpalatable as thallus, $76 \%$ of those unpalatable as extract). Extrapolating with fish where extract assays were not possible, $44 \%$ of the species were chemically defended (83\% of the species unpalatable as thallus, $53 \%$ of those tested unpalatable as extracts). Also, most (63\%) of the macroalgal species that were unpalatable as thallus to either sea stars or fish were chemically defended against amphipods.

No other macroalgal parameter appears to be important across species in determining unpalatability to potential grazers. Relative thallus toughness and a wide variety of nutritional components from macroalgae collected during the 2000 and 2001-2002 expeditions (Peters 2004, Peters et al. 2005) are summarized in Table 1. No consistent patterns were apparent in these data. Examining only macroalgal species palatable as thallus to sea stars, fish, or both (Table 3), the rank orders for thallus toughness and all nutritional parameters ranged widely, with the mean ranks all near the median. Although penetrometry is probably not an ideal measure of thallus toughness and smaller differences may have little ecological significance even if statistically significant, both the toughest (Gigartina skottsbergii, 21.5 N) and the least tough (Picconiella plumosa, $0.76 \mathrm{~N}$ ) species were palatable. Since sea stars often feed by extruding their stomachs over their prey for external digestion (Hyman 1955), thallus toughness may be relatively unimportant to them in determining palatability. However, even taking this into consideration does not reveal any overall patterns with respect to the role of thallus toughness. Protein levels, which are often considered the most important nutritional parameter in determining palatability of macroalgae (e.g. Horn \& Neighbors 1984, Duffy \& Paul 1992, Bolser \& Hay 1996), in the palatable species ranged from $1.7 \%$ dry mass in G. skottsbergii (second lowest overall) to $13.3 \%$ dry mass in Palmaria decipiens (highest overall) (Peters 2004, Peters et al. 2005). Antarctic macroalgae generally have higher protein contents than reported for temperate and tropical macroalgae (Peters 2004, Peters et al. 2005). There were also no consistent patterns when looking only at species that were unpalatable as thallus, but palatable when presented as extracts (Table 4), although thallus toughness and/or nutritional composition may be important in individual cases.

Gigartina skottsbergii, Palmaria decipiens, and Porphyra plocamiestris were the only species shown to be palatable to both the sea stars and fish (Table 3). Although a large majority of subtidal Antarctic macroalgae are perennial, these 3 species are all pseudoperennial or annual (Wiencke \& Clayton 2002) and likely invest in rapid, seasonal growth of their nonencrusting phases as an alternative to investing in chemical or morphological defenses against consumers (cf. Cronin 2001). However, this pattern cannot be generalized, since species with similar life histories such as Gymnogongrus turquetii and Delesseria lancifolia were unpalatable as thallus. When available, the noncrustose blades of $G$. skottsbergii and P. decipiens probably constitute most of the generally palatable macroalgal biomass in the study area.

With the exception of Desmarestia antarctica, all of the ecologically dominant species of brown algae in

Table 3. Summary of thallus feeding bioassay, thallus toughness, and nutritional data for species palatable to sea stars, fish, or both as thallus. $\% \mathrm{C}=$ percent carbon; \% $\mathrm{N}=$ percent nitrogen. Other abbreviations as in Table 1 (Peters 2004, Peters et al. 2005)

\begin{tabular}{|c|c|c|c|c|c|c|c|c|c|c|}
\hline \multirow{2}{*}{ Species } & \multicolumn{2}{|c|}{ Thallus } & \multirow[t]{2}{*}{ Tgh rank } & \multirow[b]{2}{*}{ Pro } & \multirow[b]{2}{*}{ Car } & \multicolumn{2}{|c|}{ Nutritional rank } & \multirow{2}{*}{$\mathrm{C:N}$} & \multirow[b]{2}{*}{$\% \mathrm{C}$} & \multirow[b]{2}{*}{$\% \mathrm{~N}$} \\
\hline & St & $\mathrm{Fi}$ & & & & Lip & Ash & & & \\
\hline Gigartina skottsbergii & $\mathrm{a}$ & a & 30 & 2 & 33 & 3 & 4 & 28 & 13 & 6 \\
\hline Palmaria decipiens & $\mathrm{a}$ & a & 10 & 34 & 27 & 26 & 15 & 1 & 17 & 31 \\
\hline Porphyra plocamiestris & $\mathrm{a}$ & $\mathrm{a}$ & & 11 & 32 & 20 & 9 & & & \\
\hline Ascoseira mirabilis & $\mathrm{a}$ & $\mathrm{R}$ & 28 & 8 & 7 & 30 & 19 & 29 & 14 & 3 \\
\hline Halopteris obovata & $\mathrm{a}$ & $\mathrm{R}$ & 12 & 4 & 11 & 14 & 33 & & & \\
\hline Phaeurus antarcticus & $\mathrm{a}$ & $\mathrm{R}$ & 16 & 32 & 1 & 33 & 24 & 22 & 23 & 16 \\
\hline Gymnogongrus antarcticus & $\mathrm{a}$ & $\mathrm{R}$ & 22 & 17 & 14 & 5 & 30 & 11 & 20 & 24 \\
\hline Pantoneura plocamioides & $\mathrm{a}$ & $\mathrm{R}$ & 5 & 18 & 21 & 10 & 17 & 16 & 19 & 18 \\
\hline Picconiella plumosa & $\mathrm{a}$ & $\mathrm{R}$ & 1 & 22 & 17 & 25 & 28 & 12 & 11 & 19 \\
\hline Iridaea cordata & $\mathrm{R}$ & $\mathrm{a}$ & 24 & 14 & 31 & 9 & 7 & 20 & 18 & 10 \\
\hline Lambia antarctica & $\mathrm{R}$ & $\mathrm{a}$ & 3 & 19 & 6 & 31 & 34 & 21 & 1 & 2 \\
\hline Georgiella confluens & $\mathrm{a}$ & & 15 & 31 & 24 & 18 & 8 & 17 & 22 & 17 \\
\hline Nereoginkgo adiantifolia & $\mathrm{a}$ & & 18 & 3 & 15 & 13 & 27 & 15 & 6 & 12 \\
\hline Phycodrys austrogeorgica & $\mathrm{a}$ & & & 9 & 18 & 17 & 20 & 2 & 5 & 22 \\
\hline Mean rank & & & 15.3 & 16.0 & 18.4 & 18.1 & 19.6 & 16.2 & 14.1 & 15.0 \\
\hline No. of species & & & 30 & 34 & 34 & 34 & 34 & 31 & 31 & 31 \\
\hline
\end{tabular}


Table 4. Summary of thallus feeding bioassay, thallus toughness, and nutritional data for species unpalatable to sea stars, fish, or both as thallus but palatable as extracts to at least 1 species which rejected it as thallus. Abbreviations as in Tables 1 \& 2

\begin{tabular}{|c|c|c|c|c|c|c|c|c|c|c|c|c|c|}
\hline \multirow{2}{*}{ Species } & \multicolumn{2}{|c|}{ Thallus } & \multicolumn{3}{|c|}{ Extract } & \multirow{2}{*}{$\begin{array}{l}\text { Tgh } \\
\text { rank }\end{array}$} & \multirow[b]{2}{*}{ Pro } & \multirow[b]{2}{*}{ Car } & \multicolumn{3}{|c|}{ - Nutritional rank - } & \multirow[b]{2}{*}{$\% \mathrm{C}$} & \multirow[b]{2}{*}{$\% \mathrm{~N}$} \\
\hline & St & $\mathrm{Fi}$ & St & $\mathrm{Fi}$ & $\mathrm{Am}$ & & & & Lip & Ash & $\mathrm{C}: \mathrm{N}$ & & \\
\hline Ascoseira mirabilis & $\mathrm{a}$ & $\mathrm{R}$ & $\mathrm{a}$ & (a) & a & 28 & 8 & 7 & 30 & 19 & 29 & 14 & 3 \\
\hline Desmarestia antarctica, first year & $\mathrm{R}$ & $\mathrm{R}$ & $\mathrm{R}$ & (a) & $\mathrm{a}$ & & 16 & 4 & 21 & 23 & 19 & 3 & 7 \\
\hline Callophyllis atrosanguinea & $\mathrm{R}$ & $\mathrm{R}$ & $\mathrm{R}$ & (a) & $\mathrm{a}$ & 17 & 6 & 20 & 1 & 26 & 7 & 7 & 21 \\
\hline Delesseria lancifolia & $\mathrm{R}$ & & $\mathrm{a}$ & & $\mathrm{R}$ & & 24 & 29 & 6 & 10 & & & \\
\hline Pachymenia orbicularis & $\mathrm{R}$ & $\mathrm{R}$ & $\mathrm{a}$ & & a & 29 & 1 & 30 & 2 & 11 & 27 & 4 & 4 \\
\hline Pantoneura plocamioides & $\mathrm{a}$ & $\mathrm{R}$ & & $\mathrm{a}$ & $\mathrm{a}$ & 5 & 18 & 21 & 10 & 17 & 16 & 19 & 18 \\
\hline Picconiella plumosa & $\mathrm{a}$ & $\mathrm{R}$ & & (a) & $\mathrm{R}$ & 1 & 22 & 17 & 25 & 28 & 12 & 11 & 19 \\
\hline Plumariopsis peninsularis & $\mathrm{R}$ & $\mathrm{R}$ & $\mathrm{R}$ & (a) & $\mathrm{R}$ & 9 & 25 & 16 & 19 & 21 & 8 & 30 & 30 \\
\hline Trematocarpus antarcticus & $\mathrm{R}$ & $\mathrm{R}$ & $\mathrm{a}$ & a & $\mathrm{a}$ & 8 & 20 & 23 & 8 & 13 & 4 & 12 & 27 \\
\hline Undescribed sp. 1 & $\mathrm{R}$ & $\mathrm{R}$ & $\mathrm{a}$ & $\mathrm{R}$ & $\mathrm{R}$ & 21 & 5 & 28 & 4 & 22 & 14 & 16 & 20 \\
\hline Lambia antarctica & $\mathrm{R}$ & $\mathrm{a}$ & $\mathrm{a}$ & & $\mathrm{a}$ & 3 & 19 & 6 & 31 & 34 & 21 & 1 & 2 \\
\hline Mean rank & & & & & & 13.4 & 14.9 & 18.3 & 14.3 & 20.4 & 15.7 & 11.7 & 15.1 \\
\hline No. of species & & & & & & 30 & 34 & 34 & 34 & 34 & 31 & 31 & 31 \\
\hline
\end{tabular}

the study area were chemically defended against all 3 species of animals in bioassays. First- and secondyear $D$. antarctica thallus were each unpalatable to both sea stars and fish, but responses to extracts were mixed. Weak secondary metabolite chemical defenses might interact with thallus toughness or nutritional quality to result in the unpalatability observed in $D$. antarctica thalli, but sequestration of sulfuric acid in this species is more likely to play a role. D. antarctica differs from other Antarctic members of the Desmarestiaceae, which together form the basal clade in the family, by sequestering inorganic acids in its thallus (Moe \& Silva 1989, Peters et al. 1997). Moe \& Silva (1989) reported that the $\mathrm{pH}$ of a slurry of fresh $D$. antarctica was 4.5. This is much less acidic than reported for temperate zone Desmarestia spp. (reviewed by Pelletreau \& Muller-Parker 2002), where sequestration of sulfuric acid in the thallus is believed to deter herbivory (Anderson \& Velimirov 1982, Pelletreau \& Muller-Parker 2002). Agar-based artificial foods are strongly rejected by Odontaster validus at $\mathrm{pH} \leq 5$ (McClintock et al. 2004). Our alginate-based artificial foods will not gel at $\mathrm{pH}<6$ (M. Amsler unpubl. data), yet we had no problems making alginate-based foods with $D$. antarctica extracts. Most if not all of the acidity of $D$. antarctica was probably neutralized by our extraction process, as we previously observed with ascidians (McClintock et al. 2004). It seems likely that the relatively weak secondary metabolite defenses we observed could be working in combination with weak acidity to make $D$. antarctica thalli unpalatable.

Macroalgae have long been discussed as an important source of carbon for detrital food webs along the Antarctic Peninsula, and our results indicate that very little of the total standing biomass of macroalgae is likely to be consumed directly by herbivores. The same situation is true of temperate kelp forests, where a majority of the macroalgal biomass is released into detrital food webs rather than being directly grazed and where most macroalgae are also perennial (Vadas 1985, Foster 1992, Vadas \& Elner 1992). In some instances the dominant macroalgae are unpalatable to herbivores, as in Antarctica (Vadas \& Elner 1992), but other kelp communities are quite different in that the dominant species are palatable to herbivores and are maintained in abundance via complex interactions with herbivores and their predators (Elner \& Vadas 1990, Foster 1992). Microbial activity may be important in making Antarctic macroalgal carbon available to herbivorous animals. Reichardt \& Deickman (1985) reported that a mixed-species group of Antarctic amphipods consumed partially degraded Himantothallus grandifolius over 5 times faster than fresh thallus and that they consumed partially degraded Palmaria decipiens (as Leptosomia simplex) twice as fast as fresh thallus.

\section{Comparisons to other regions and taxa}

Other than our previous study at McMurdo Sound, Antarctica, where only 2 species of non-encrusting macroalgae were present (Amsler et al. 1998), we are not aware of published reports on palatability or chemical defenses of macroalgae that are directly comparable to the present study in terms of both approach and methodology. Many studies in other geographic areas have looked at palatability and/or defenses in multiple, 
sympatric macroalgal species, but in most cases not with the approach of sampling (nearly) the entire flora or a random sample thereof. Paul \& Hay (1986) did take a similar approach in conducting field feedingpreference bioassays on all species of tropical macroalgae they could collect in sufficient quantities from coral reefs in the Florida Keys, USA. A total of 82 macroalgal species were assayed, many in multiple experiments. They defined macroalgae as low preference if $<25 \%$ of individuals were consumed by the sympatric fish fauna, as high preference if $>75 \%$ were consumed, and as intermediate preference if 25 to $75 \%$ of individuals were consumed. Based on the data presented in their Fig. 1, approximately $33 \%$ of the macroalgal species were always low preference to the fish community, and an additional 10\% were low preference in some experiments and intermediate preference in others. Approximately $22 \%$ of the macroalgal species were always high preference to the fish community, with an additional $4 \%$ sometimes high preference and sometimes intermediate preference. Although these results are not directly comparable to our data from bioassays where no alternate food choice was available, since only $17 \%$ of the Antarctic species were palatable as thallus to fish and $37 \%$ to the sea stars, on a species-by-species basis, Antarctic macroalgae probably are neither markedly more nor markedly less palatable to sympatric consumers than are tropical macroalgae in the communities studied by Paul \& Hay (1986). The extent to which chemical defenses are involved in unpalatability have yet to be quantified on a comparable scale with tropical macroalgae and potentially could be higher than in Antarctic macroalgae.

Investigations of chemical defenses in 2 tropical invertebrate taxa are more directly comparable to the present study. Pawlik et al. (1995) performed no-choice laboratory fish-feeding bioassays with lipophilic extracts of 71 species of sponges collected in a variety of habitats from several areas of the Caribbean Sea. This represented all species that were collected in sufficient quantity for assays (J. Pawlik pers. comm.). Overall, $69 \%$ of the sponge species were unpalatable as extracts presented in artificial foods. Unextracted tissues were not assayed for palatability, but those sponge species most commonly eaten by fish in nature had palatable extracts. O'Neal \& Pawlik (2002) used this same approach to examine the palatability of extracts from 32 species of Caribbean gorgonian corals, and all were unpalatable to fish. In summary, Caribbean sponges are somewhat more likely to contain chemical defenses, while gorgonians are obviously much more likely to contain chemical defenses in comparison to the Antarctic macroalgae in the present study.

\section{Absence of nitrogenous secondary metabolites}

Other than mycosporine-like amino acids (MAAs), which defend against UV radiation damage and are common in marine macroalgae throughout the world (McClintock \& Karentz 1997, Hoyer et al. 2001, Karentz 2001, Karentz \& Bosch 2001), we are not aware of reports of nitrogen-containing secondary metabolites in Antarctic macroalgae. To date, 50 non-MAA secondary metabolites have been reported from Antarctic macroalgae (Amsler et al. 2001b, Ankisetty et al. 2004, Blunt \& Munro 2004), none of which contain nitrogen. As described above, in the present study we could detect no nitrogen-containing compounds by TLC staining from extracts of 24 common macroalgal species that were prepared by an acid-extraction process that should have selected for alkaloids and similar compounds. These results do not mean that there are no nitrogenous secondary metabolites at all in the macroalgae examined, but do indicate that if present, just as in macroalgae from other regions, such compounds are not abundant. Nitrogenous secondary metabolites are, however, found in Antarctic invertebrates and constitute a majority of the compounds identified to date from Antarctic sponges (Amsler et al. 2001b).

Whether or not alkaloids or other nitrogen-containing secondary metabolites are identified in Antarctic macroalgae in the future, the lack of any to date, even when specifically targeted as in the present study, certainly indicates that such compounds are not common in these nitrogen-replete, carbon-limited Antarctic macroalgae, as would be predicted by the carbon-nutrient balance hypothesis or the resource allocation model (Bryant et al. 1983, Coley et al. 1985). Moreover, our results, combined with the existing chemical literature on Antarctic macroalgae, clearly indicate that the rarity of nitrogenous secondary metabolites in (eukaryotic) marine macroalgae cannot be explained simply as an evolutionary response to nitrogen limitation in the sea, but rather is likely the result of some basic, yet unrecognized, aspect of macroalgal physiology.

Acknowledgements. We are very grateful to Drs R. Moe, C. Wiencke, and M. Clayton for generous assistance with macroalgal species identifications. However, any misidentifications of field material are the responsibility of C.D.A. and K.I. The final version of the manuscript was improved based on suggestions from Dr R. Thacker, Dr V. A. Fairhead, and 3 anonymous reviewers. We also thank Dr K. Conlan for identification of Gondogeneia antarctica, A. Mahan for laboratory assistance, A. Shriver for collecting Cladophora vagabunda, and the employees and subcontractors of Raytheon Polar Services Company and of Antarctic Support Associates for logistical support in Antarctica. This research was facilitated by National Science Foundation awards to C.D.A. and J.B.M. 
(OPP-9814538, OPP-0125181) and to B.J.B. (OPP-9901076, OPP-0125152). The participation of J.M.H. was made possible by a supplementary award to OPP-9814538 from the National Science Foundation Teachers Experiencing Antarctica and the Arctic Program.

\section{LITERATURE CITED}

Amsler CD, Rowley RJ, Laur DR, Quetin LB, Ross RM (1995) Vertical distribution of Antarctic peninsular macroalgae: cover, biomass and species composition. Phycologia 34: $424-430$

Amsler CD, McClintock JB, Baker BJ (1998) Chemical defense against herbivory in the Antarctic marine macroalgae Iridaea cordata and Phyllophora antarctica (Rhodophyceae). J Phycol 34:53-59

Amsler CD, McClintock JB, Baker BJ (2000) Chemical defenses in Antarctic marine organisms: a reevaluation of the latitudinal hypothesis. In: Davidson B, HowardWilliams C, Brody P (eds) Antarctic ecosystems: models for wider ecological understanding. Caxton Press, Christchurch, p 166-172

Amsler CD, McClintock JB, Baker BJ (2001a) Secondary metabolites as mediators of trophic interactions among Antarctic marine organisms. Am Zool 41:17-26

Amsler CD, Iken KB, McClintock JB, Baker BJ (2001b) Secondary metabolites from Antarctic marine organisms and their ecological implications. In: McClintock JB, Baker BJ (eds) Marine chemical ecology. CRC Press, Boca Raton, FL, p 195-226

Anderson RJ, Velimirov B (1982) An experimental investigation of the palatability of kelp bed algae to the sea urchin Parechinus angulosus Leske. PSZN I: Mar Ecol 3:357-373

Ankisetty S, Nandiraju S, Win H, Park YC and 10 others (2004) Chemical investigation of predator-deterred macroalgae from the Antarctic Peninsula. J Nat Prod 67:1295-1302

Baker BJ (1996) $\beta$-carboline and isoquinoline alkaloids from marine organisms. In: Pelletier SW (ed) Alkaloids: chemical and biological perspectives, Vol 10. Pergamon Press, Oxford, p 357-407

Bakus GJ, Green G (1974) Toxicity in sponges and holothurians: a geographic pattern. Science 185:951-953

Barrera-Oro ER, Casaux RJ (1990) Feeding selectivity in Notothenia neglecta, Nybelin, from Potter Cove, South Shetland Islands, Antarctica. Antarct Sci 2:207-213

Becerro MA, Thacker RW, Turon X, Uriz MJ, Paul VJ (2003) Biogeography of sponge chemical ecology: comparisons of tropical and temperate defenses. Oecologia 135:91-101

Blunt JW, Munro MHG (2004) MarinLit. University of Canterbury, Christchurch

Bolser RC, Hay ME (1996) Are tropical plants better defended? Palatability and defenses of temperate vs. tropical seaweeds. Ecology 77:2269-2286

Brand TE (1974) Trophic interactions and community ecology of the shallow-water marine benthos along the Antarctic Peninsula. PhD thesis, University of California, Davis, CA

Brouwer PEM, Geilen EFM, Gremmen NJM, van Lent F (1995) Biomass cover and zonation pattern of sublittoral macroalgae at Signy Island, South Orkney Islands, Antarctica. Bot Mar 38:259-270

Bryant JP, Chapin FS III, Klein DR (1983) Carbon/nutrient balance of boreal plants in relation to vertebrate herbivory. Oikos 40:357-368

Cetrulo GL, Hay ME (2000) Activated chemical defenses in tropical versus temperate seaweeds. Mar Ecol Prog Ser 207:243-253
Chung H, Oh YS, Lee IK, Kim DY (1994) Macroalgal vegetation of Maxwell Bay in King George Island, Antarctica. Kor J Phycol 9:47-58

Coley PD, Bryant JB, Chapin FS III (1985) Resource availability and plant antiherbivore defense. Science 230:895-899

Cronin G (2001) Resource allocation in seaweeds and marine invertebrates: chemical defense patterns in relation to defense theories. In: McClintock JB, Baker BJ (eds) Marine chemical ecology. CRC Press, Boca Raton, FL, p 325-353

Dawson R, Schramm W, Bolter M (1985) Factors influencing the production, decomposition and distribution of organic matter in Admiralty Bay, King George Island. In: Siegfried WR, Condy PR, Laws RM (eds) Antarctic nutrient cycles and food webs. Springer-Verlag, Berlin, p 109-114

Dearborn JH (1977) Foods and feeding characteristics of Antarctic asteroids and ophiuroids. In: Llano GA (ed) Adaptations within Antarctic ecosystems. Smithsonian Institution, Washington, DC, p 293-326

De Broyer C, Chapelle G, Duchesne PA, Munn R, Nyssen F, Scailteur Y, van Roozendael F, Dauby P (1988) Structural and ecofunctional biodiversity of the amphipod crustacean benthic taxocoenoses in the Southern Ocean. In: Arntz WE, Gutt J (eds) The expedition ANTXV/3 (EASIZ II) of RV 'Polarstern' in 1988. Ber Polarforsch 301:163-174

DeLaca TE, Lipps JH (1976) Shallow-water marine associations, Antarctic Peninsula. Antarct J US 11:12-20

Drew EA, Hastings RM (1992) A year-round ecophysiological study of Himantothallus grandifolius (Desmarestiales, Phaeophyta) at Signy Island, Antarctica. Phycologia 31: 262-277

Duffy JE, Hay ME (1991) Food and shelter as determinants of food choice by an herbivorous marine amphipod. Ecology 72:1286-1298

Duffy JE, Paul VJ (1992) Prey nutritional quality and effectiveness of chemical defenses against tropical reef fishes. Oecologia 90:333-339

Dunton KH (2001) $\delta^{15} \mathrm{~N}$ and $\delta^{13} \mathrm{C}$ measurements of Antarctic Peninsula fauna: trophic relationships and assimilation of benthic seaweeds. Am Zool 41:99-112

Elner RW, Vadas RL Jr (1990) Inference in ecology: the sea urchin phenomenon in the northwest Atlantic. Am Nat 136:108-125

Fischer G, Wiencke C (1992) Stable carbon isotope composition, depth distribution and fate of macroalgae from the Antarctic Peninsula region. Polar Biol 12:341-348

Foster MS (1992) How important is grazing to seaweed evolution and assemblage structure in the north-east Pacific? In: John DM, Hawkins SJ, Price JH (eds) Plant-animal interactions in the marine benthos. Clarendon Press, Oxford, p 61-85

Gaines SD, Lubchenco J (1982) A unified approach to marine plant-herbivore interactions. II. Biogeography. Annu Rev Ecol Syst 13:111-138

Gordon AL, Molinelli EJ (1982) Southern Ocean atlas: thermohaline and chemical distributions and the atlas data set. Columbia University Press, New York

Graeve M, Dauby P, Scailteur Y (2001) Combined lipid, fatty acid and digestive tract content analyses: a penetrating approach to estimate feeding modes of Antarctic amphipods. Polar Biol 24:853-862

Harper MK, Bubni TS, Copp BR, James RD, and 7 others (2001) Introduction to the chemical ecology of marine natural products. In: McClintock JB, Baker BJ (eds) Marine chemical ecology. CRC Press, Boca Raton, FL p 3-69

Harrison WG, Cota GF (1991) Primary production in polar waters: relation to nutrient availability. Polar Res 10: $87-104$ 
Hay ME, Fenical W (1988) Marine plant-herbivore interactions: the ecology of chemical defense. Annu Rev Ecol Syst 19:111-145

Hay ME, Steinberg PD (1992) The chemical ecology of plant-herbivore interactions in marine versus terrestrial communities. In: Rosenthal GA, Berenbaum MR (eds) Herbivores: their interactions with secondary plant metabolites. Vol II. Evolutionary and ecological processes. Academic Press, New York

Hay ME, Kappel QE, Fenical W (1994) Synergisms in plant defenses against herbivores: interactions of chemistry, calcification, and plant quality. Ecology 75:1714-1726

Heywood RB, Whitaker TM (1984) The Antarctic marine flora. In: Laws RM (ed) Antarctic ecology, Vol 2. Academic Press, London, p 373-419

Holm-Hansen O, El-Sayed SZ, Franceschini GA, Cuhel RL (1977) Primary production and the factors controlling phytoplankton growth in the Southern Ocean. In: Llano GA (ed) Adaptations within Antarctic ecosystems. Smithsonian Institution, Washington, DC, p 11-50

Horn MH, Neighbors MA (1984) Protein and nitrogen assimilation as a factor in predicting the seasonal macroalgal diet of the monkeyface prickleback. Trans Am Fish Soc 113:388-396

Hoyer K, Karsten U, Sawall T, Wiencke C (2001) Photoprotective substances in Antarctic macroalgae and their variation with respect to depth distribution, different tissues and developmental stages. Mar Ecol Prog Ser 211:117-129

Hyman LH (1955) The invertebrates: Echinodermata. McGraw-Hill, New York

Iken K, Barrera-Oro ER, Quartino ML, Casaux RJ, Brey T (1997) Grazing in the Antarctic fish Notothenia coriiceps: Evidence for selective feeding on macroalgae. Antarct Sci 9:386-391

Iken K, Quartino ML, Barrera-Oro E, Palermo J, Wiencke C, Brey T (1998) Trophic relations between macroalgae and herbivores. Ber Polarforsch 299:258-262

Iken K, Quartino ML, Wiencke C (1999) Histological identification of macroalgae from stomach contents of the Antarctic fish Notothenia coriiceps using semi-thin sections. Mar Ecol 20:11-17

Jazdzewski K, De Broyer C, Pudlarz M, Zieliński D (2001) Seasonal fluctuations of vagile benthos in the uppermost sublittoral of a maritime Antarctic fjord. Polar Biol 24: 910-917

Karentz D (2001) Chemical defenses of marine organisms against solar radiational exposure: UV-absorbing mycosporine-like amino acids and scytonemin. In: McClintock JB, Baker BJ (eds) Marine chemical ecology. CRC Press, Boca Raton, FL, p 481-520

Karentz D, Bosch I (2001) Influence of ozone-related increases in ultraviolet radiation on Antarctic marine organisms. Am Zool 41:3-16

Kazlauskas R, Murphy PT, Quinn RJ, Wells RJ (1977) A new class of halogenated lactones from the red alga Delisea fimbriata (Bonnemaisonaceae). Tetrahedron Lett 1:37-40

Kennett JP (1977) Cenozoic evolution of Antarctic glaciation, the circum-Antarctic ocean, and their impact on global paleoceanography. J Geophys Res 82:3843-3860

Kennett JP, Barker PF (1990) Latest Cretaceous to Cenozoic climate and oceanographic developments in the Weddell Sea, Antarctica: an ocean-drilling perspective. Proc Ocean Drilling Program Sci Res 113:937-960

Littler MM, Littler DS (1980) The evolution of thallus form and survival strategies in benthic marine macroalgae: field and laboratory tests of a functional form model. Am Nat 116:25-44
McClintock JB (1994) The trophic biology of Antarctic echinoderms. Mar Ecol Prog Ser 111:191-202

McClintock JB, Baker BJ (1997) Palatability and chemical defense in the eggs, embryos and larvae of shallow-water Antarctic marine invertebrates. Mar Ecol Prog Ser 154: 121-131

McClintock JB, Baker BJ (eds) (2001) Marine chemical ecology. CRC Press, Boca Raton, FL

McClintock JB, Karentz D (1997) Mycosporine-like amino acids in 38 species of subtidal marine organisms from McMurdo Sound, Antarctica. Antarct Sci 9:392-398

McClintock JB, Amsler MO, Amsler CD, Southworth KJ, Petrie C, Baker BJ (2004) Biochemical composition, energy content and chemical antifeedant and antifoulant defenses of the colonial Antarctic ascidian Distaplia cylindrica. Mar Biol 145:885-894

Moe RL, DeLaca TE (1976) Occurrence of macroscopic algae along the Antarctic Peninsula. Antarct J US 11:20-24

Moe RL, Silva PC (1989) Desmarestia antarctica (Desmarestiales, Phaeophyceae), a new ligulate Antarctic species with an endophytic gametophyte. Plant Syst Evol 164: 273-283

Momo F, Bogazzi E, Duttweiler F (1998) Amphipods of Potter Cove: community composition biology and growth. Ber Polarforsch 299:144-149

Neushul M (1965) Diving observation of sub-tidal Antarctic marine vegetation. Bot Mar 8:234-243

O'Neal W, Pawlik JR (2002) A reappraisal of the chemical and physical defenses of Caribbean gorgonian corals against predatory fishes. Mar Ecol Prog Ser 240:117-126

Paul VJ, Hay ME (1986) Seaweed susceptibility to herbivory: chemical and morphological correlates. Mar Ecol Prog Ser 33:255-264

Paul V, Cruz-Rivera E, Thacker RW (2001) Chemical mediation of macroalgal-herbivore interactions: ecological and evolutionary perspectives. In: McClintock JB, Baker BJ (eds) Marine chemical ecology. CRC Press, Boca Raton, FL, p 227-266

Pavia H, Toth GB (2000) Influence of light and nitrogen on the phlorotannin content of the brown seaweeds Ascophyllum nodosum and Fucus vesiculosus. Hydrobiologia 440: 299-305

Pawlik JR, Chanas B, Toonen RJ, Fenical W (1995) Defenses of Caribbean sponges against predatory reef fish. I. Chemical deterrency. Mar Ecol Prog Ser 127:183-194

Peckol P, Yates JL (1997) Inducible phlorotannin levels in brown algae from backreef sites. Proc 8th Int Coral Reef Symp 2:1259-1262

Pelletreau KN, Muller-Parker G (2002) Sulfuric acid in the phaeophyte alga Desmarestia munda deters feeding by the sea urchin Strongylocentrotus droebachiensis. Mar Biol 141:1-9

Peters AF, van Oppen MJH, Wiencke C, Stam WT, Olsen JL (1997) Phylogeny and historical ecology of the Desmarestiaceae (Phaeophyceae) support a southern hemisphere origin. J Phycol 33:294-309

Peters KJ (2004) A comparative analysis of the nutritional and elemental composition of macroalgae from the western Antarctic Peninsula. MS thesis, University of Alabama at Birmingham, AL

Peters KJ, Amsler CD, Amsler MO, McClintock JB, Dunbar RB, Baker, BJ (2005) A comparative analysis of the nutritional and elemental composition of macroalgae from the western Antarctic Peninsula. Phycologia 44:in press

Peterson CH, Renaud PE (1989) Analysis of feeding preference experiments. Oecologia 80:82-86

Quartino ML, Klöser H, Schloss IR, Wiencke C (2001) Biomass 
and associations of benthic marine macroalgae from the inner Potter Cove, King George Island, Antarctica, related to depth and substrate. Polar Biol 24:349-355

Reichardt W, Dieckmann G (1985) Kinetics and trophic role of bacterial degradation of macro-algae in Antarctic coastal waters. In: Siegfried WR, Condy PR, Laws RM (eds) Antarctic nutrient cycles and food webs. Springer-Verlag, Berlin, p 115-122

Richardson MG (1977) The ecology including physiological aspects of selected Antarctic marine invertebrates associated with inshore macrophytes. PhD thesis, Department of Zoology, University of Durham

Sokal RR, Rohlf FJ (1995) Biometry. WH Freeman, New York

Steinberg PD, Paul V (1990) Fish feeding and chemical defense of tropical brown algae in Western Australia. Mar Ecol Prog Ser 58:253-259

Steneck RS, Watling L (1982) Feeding capabilities and limitation of herbivorous molluscs: a functional approach. Mar Biol 68:299-312

Targett NM, Arnold TM (1998) Predicting the effects of brown algal phlorotannins on marine herbivores in tropical and temperate oceans. J Phycol 34:195-205

Vadas RL (1985) Herbivory. In: Littler MM, Littler DS (eds) Handbook of phycological methods. Ecological field methods: macroalgae. Cambridge University Press, Cambridge, p 531-572

Editorial responsibility: Joseph Pawlik (Contributing Editor), Wilmington, North Carolina, USA
Vadas RL, Elner RW (1992) Plant-animal interactions in the north-west Atlantic. In: John DM, Hawkins SJ, Price JH (eds) Plant-animal interactions in the marine benthos. Clarendon Press, Oxford, p 33-60

Valiela I, Geist M, McClelland J, Tomasky G (2000) Nitrogen loading from watersheds to estuaries: verification of the Waquoit Bay nitrogen loading model. Biogeochemistry 49: $277-293$

Van Alstyne KL, Paul VJ (1990) The biogeography of polyphenolic compounds in marine macroalgae: temperate brown algal defenses deter feeding by tropical herbivorous fishes. Oecologia 84:158-163

Weykam G, Gómez I, Wiencke C, Iken K, Klöser H (1996) Photosynthetic characteristics and $\mathrm{C}: \mathrm{N}$ ratios of macroalgae from King George Island (Antarctica). J Exp Mar Biol Ecol 204:1-22

Wiencke C, Clayton MH (2002) Antarctic seaweeds: synopsis of the Antarctic benthos, Vol 9. ARG Gantner Verlag, Ruggell

Wiencke C, Stolpe U, Lehmann H (1991) Morphogenesis of the brown alga Desmarestia antarctica cultivated under seasonally fluctuating Antarctic daylengths. Ser Cient Inst Antartico Chil 41:65-78

Zieliński K (1990) Bottom macroalgae of Admiralty Bay (King George Island, South Shetland Islands). Polar Res 11: 95-131

Submitted: October 13, 2004; Accepted: January 4, 2005 Proofs received from author(s): May 17, 2005 